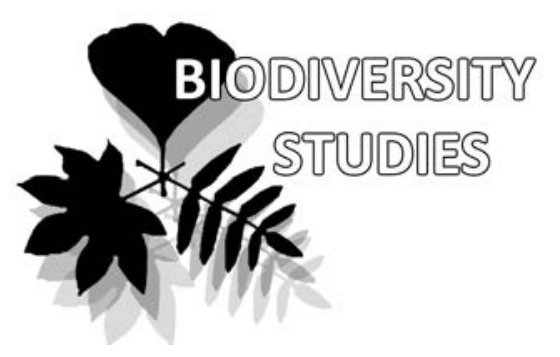

Liudmila Konoreva $a^{1,2,3 *}$

e-mail: ajdarzapov@yandex.ru

Sergey Chesnokov ${ }^{1,3}$

e-mail: lukinbrat@mail.ru

Lidia Yakovchenko ${ }^{4}$

e-mail: lidiyakovchenko@mail.ru

Yoshihito Ohmura

e-mail: ohmura-y@kahaku.go.jp

Evgeny A. Davydov ${ }^{6}$

e-mail: eadavydov@yandex.ru

${ }^{1}$ Botanical Garden-Institute FEB RAS, Vladivostok, Russia

${ }^{2}$ The Polar-Alpine Botanical GardenInstitute of the Kola Science Centre RAS, Kirovsk, Russiaa

${ }^{3}$ Komarov Botanical Institute RAS, St. Petersburg, Russiaa

${ }^{4}$ Federal Scientific Center of East Asian Terrestrial Biodiversity FEB RAS, Vladivostok, Russia

${ }^{5}$ Department of Botany, National Museum of Nature and Science, Tsukuba, Ibaraki, Japan

${ }^{6}$ Altai State University, Barnaul, Russia

* corresponding author

Manuscript received: 18.12 .2019

Review completed: 19.01.2020

Accepted for publication: 25.05.2020

Published online: 04.06.2020

\section{New records to the lichen biota of Russia, 1 - Sakhalin Region, with new records for the Russian Far East and the Asian part of Russia}

\author{
Liudmila Konoreva*1,2,3, Sergey Chesnokov ${ }^{1,3}$, Lidia Yakovchenko ${ }^{4}$, \\ Yoshihito Ohmura ${ }^{5}$ Evgeny A. Davydov ${ }^{6}$
}

\begin{abstract}
A B S T R A C T
For the first time, 39 species of lichens are presented for Sakhalin Region (Sakhalin, Iturup and Kunashir Islands) including Carbonicola myrmecina, Chaenotheca bispidula, Micarea nigella, Placynthiella oligotropha, Polycauliona phlogina and Porpidia bydrophila - new to the Russian Far East; Alyxoria culmigena, Caloplaca stillicidiorum, Cladonia borealis, C. gracilis ssp. turbinata, C. stygia, Lecidella carpathica, Rhizocarpon expallescens and R. superficiale - new for Southern part of the Russian Far East; 19 species are reported for the first time for Sakhalin, six - for Iturup Island, and one - for Kunashir Island. For each species, the general distribution, habitat, and taxonomy, indicating differences from related species and location are presented. 14 species were excluded from the lichen list of Sakhalin Region predominanty from Kunashir Island. All specimens of Pseudocyphellaria crocata published from the Russian Far East were reidentified as $P$. perpetua.
\end{abstract}

Ke ywords : new records, lichens, taxonomy, distribution, Asian Russia, Far East, Sakhalin Region, Sakhalin Island, Iturup Island, Kunashir Island

\section{P E 3 Ю M E}

Конорева М.А., Чесноков С.В., Яковченко М.С., Омура Й., АавыАов Е.А. Новые находки Аля михенобиоты России, 1 - Сахалинская обАасть, с новыми находками Аля российского Аальнего Востока и азиатской части России. Впервые Аля лихенофлоры Сахалинской области (о-ва Сахалин, Итуруп и Кунашир) приведено 39 видов, среди них Carbonicola myrmecina, Chaenotheca hispidula, Micarea nigella, Placynthiella oligotropha, Polycauliona phlogina и Porpidia bydrophila - новые вилы мля Аальнего Востока России; Alyxoria culmigena, Caloplaca stillicidiorum, Cladonia borealis, C. gracilis ssp. turbinata, C. stygia, Lecidella carpathica, Rhizocarpon expallescens and R. superficiale - новые виды Аля юга российского Аальнего Востока; 19 видов впервые приведены Аля о. Сахалин, 6 - Аля о. Итуруп и 1 - Аля о. Кунашир. А^я кажАого виАа представлены общее распространение, местообитания, таксономия с указанием отличий от близких виАов и местонахожАения. Из списка Аишайников Сахалинской области исключены 14 видов, в основном по материалам с о. Кунашир (10 вицов). Все опубликованные с Аальнего Востока об̆разцы Pseudocyphellaria crocata переопределены как P. perpetua.

Ключевые слова: новые находки, Аишайники, таксономия, распространение, Азиатская Россия, Аальний Восток, Сахалинская область, остров Сахалин, остров Итуруп, остров Кунашир
Thirty nine lichen species are reported as new to $\mathrm{Sa}$ khalin Region (Sakhalin and Kurily Islands) basing on field explorations, as well as taxonomic revisions of herbarium materials. Six species are new to Far East, 8 - to Southern part of the Russian Far East, 19 - to Sakhalin Island, 6 - to Iturup Island and 1 - to Kunashir Island. As a result of the revision of herbarium collections, 14 species were excluded from the lichen list of the Sakhalin Region.

\section{Abbreviations adopted:}

RFE = Far Eastern Federal District; Amu = Amur Region; $\mathbf{C h u}=$ Chukotka Autonomous Area; Jew = Jewish Autonomous Region; Kam = Kamchatka Territory; Kha = Khabarovsk Territory; Mag = Magadan Region; Pri = Primorye Territory; Yak $=$ Republic of Sakha (Yakutia).

SIB $=$ Siberian Federal District; $\mathbf{B a i}=$ Trans-Baikal Territory; Bur = Republic of Buryatia; Irk = Irkutsk Region; Kra $=$ Krasnoyarsk Territory.

\section{ANAMYLOPSORACEAE Lumbsch \& Lunke Anamylopsora pulcherrima (Vain.) Timdal \\ Contributor: Sergey Chesnokov}

Distribution and habitat. Inhabits rocks. In other regions it also occurs on both calciferous and siliceous rocks. It is widely distributed in the mountains and aridic regions; RFE: Pri and Kha (Tchabanenko 2002, Yakovchenko et al. 2013), Amu (Pchelkin 2008). It is reported for the first time for Sakhalin.

Taxonomical notes. Anamylopsora Timdal is the monotypic genus with the only species. This species was excluded from the genus Psora Hoffm. by Timdal (1984) owing to presence of non-amyloid tholus and hymenial gelatin as well as different type of upper cortex and pycnidia and also absence of antraquinones in hymenium (Timdal 1991).

Examined specimens (new records). Sakhalin Island, vicinity of Yuzhno-Sakhalinsk, Susunaysky Range, Chekhov Peak, 4659'48.8'N 142 50'06.8'E, alt. $977 \mathrm{~m}$, rocks, on stone, 28.06.2017, leg. S.V. Chesnokov (231). 


\section{ARTHONIACEAE Rchb.}

\section{Arthonia punctiformis Ach.}

\section{Contributor: Liudmila Konoreva}

Distribution and habitat. Found on bark of Caragana arborescens and Populus maximowiczii. In other regions it also occurs on smooth bark of a wide range of trees and shrubs, often on twigs. It is widely distributed from the boreal to temperate regions; RFE: Kam (Himelbrant et al. 2014, 2019), Pri (Skirina 2010, 2015b). It is reported for the first time for Sakhalin.

Taxonomical notes. This species belongs to the genus Arthonia described by E. Acharius in 1806. It includes over 250 species with Trentepholia as photobiont and rounded asci. A. punctiformis is distinguished from similar $A$. radiata (Pers.) Ach. by the less conspicuous, apparently non-lichenized thallus and rarely branched, shallower apothecia.

Examined specimens (new records). Sakhalin Island, Yuzhno-Sakhalinsk, Sakhalin Botanical Garden, $46^{\circ} 56^{\prime} 40.1^{\prime \prime} \mathrm{N} 142^{\circ} 45^{\prime} 46.7^{\prime \prime} \mathrm{E}$, alt. $135 \mathrm{~m}$, riparian secondary forest with Larix leptolepis, on bark of Caragana arborescens, 07.05.2017, leg. L.A. Konoreva (1); ibid., 4656'36.3"N 142 46'01.7"E, alt. $96 \mathrm{~m}$, stream bank with Alnus hirsuta and Populus maximowiczii, on bark of Populus maximowiczii, 07.05.2017, leg. L.A. Konoreva (17).

\section{CARBONICOLACEAE Bendiksby $\&$ Timdal Carbonicola myrmecina (Ach.) Bendiksby \& Timdal}

Contributor: Liudmila Konoreva

Distribution and habitat. Found on burnt tree trunk. In other regions it also occurs of burnt wood and rarely on bark of coniferous trees. It is scattered distributed from the boreal to temperate zones; RFE: Yak (Galanina 2016) and SIB: Bai (Yakovchenko 2009). It is reported for the first time for the Russian Far East.

Taxonomical notes. Species of the genus Carbonicola were belonging to Hypocenomyce M. Choisy until 2013 and then combined to the new genus described by M. Bendiksby \& E. Timdal (2013) basing of brown, convex apothecia; a pale exciple composed of entirely conglutinated hyphae; a brown epihymenium lacking amorphous substances; asci with a deeply amyloid tube; and in the main secondary chemistry consisting of compounds of the colensoic acid complex. The authors inscribe three species in this genus including C. myrmecina (三 Hypocenomyce castaneocinerea (Räsänen) Timdal). From the closely related $C$. antracophila (Nyl.) Bendiksby \& Timdal C. myrmecina differs by the uniform coloring of thalline squamules (without a pale margin) and by chemistry (Carbonicola myrmecina contains colensoic acid complex, whereas C. antracophila - fumarprotocetraric and protocetraric acids).

Examined specimens (new records). Sakhalin Island, Tomarinsky district, Krasnogorsky Reserve, vicinity of Ainskoe Lake, $48^{\circ} 30^{\prime} 42.9^{\prime \prime N} 142^{\circ} 00^{\prime} 26.8^{\prime \prime E}$, alt. 6 m, Larix forest near of road, on a burnt tree trunk, 15.05.2017, leg. L.A. Konoreva (153).

\section{CLADONIACEAE Zenker \\ Cladonia borealis $\mathrm{S}$. Stenroos}

Contributor: Sergey Chesnokov

Distribution and habitat. Inhabits soil. In other regions it occurs on soil, rock outcrops, rarely on peat and rotten wood. It is widely distributed from the Arctic to boreal zones, and in the mountains; RFE: Kam (Himelbrant et al. 2014, 2019). It is reported for the first time for southern part of the Russian Far East.

Taxonomical notes. For a long time Cladonia borealis was not distinguished from C. coccifera (L.) Willd., but in 1989 it was described by S. Stenroos (1989) as a separate species. According to phylogenetic analysis (Stenroos et al. 2002) C. borealis is not closely related to $C$. coccifera and $C$. pleurota (Flörke) Schaer. In the herbarium, this species never produces crystal needles on the surface. Thus, old specimens of $C$. borealis differ from $C$. coccifera, $C$. pleurota and $C$. diversa Asperges by the chemistry (detected by TLC). Fresh specimens are distinguishable by more smoothly corticated podetia.

Examined specimens (new records). Sakhalin Island, Tomarinsky district, Krasnogorsky Reserve, road between Ainskoe Lake and the sea, $48^{\circ} 27^{\prime} 29.1^{\prime \prime N} 142^{\circ} 03^{\prime} 06.2^{\prime \prime} \mathrm{E}$, alt. $4 \mathrm{~m}$, sea shore with mixed grass meadow, on soil, 13.05.2017, leg. S.V. Chesnokov (24).

\section{Cladonia gracilis ssp. turbinata (Ach.) Ahti}

Contributor: Liudmila Konoreva

Distribution and habitat. Inhabits bark of Picea sp. In other regions it occurs on soil in forest (dry to mesic conditions), rock outcrops, bog hummocks and rotten wood. It is widely distributed from the Arctic to temperate regions; RFE: Kam (Himelbrant et al. 2014, 2019). It is reported for the first time for southern part of the Russian Far East.

Taxonomical notes. It is a polymorphic species with a lot of intraspecific taxa. This subspecies is the most widespread in C. gracilis (L.) Willd. It is characterized by wide scyphi (to $1 \mathrm{~cm}$ in diameter) and absence of subulate podetia. From Cladonia phyllophora Hoffm. it differs by absence of arachnoid cortex of podecia and from C. cervicornis (Ach.) Flot. - by absence of proliferation of scyphi (Ahti 1980).

Examined specimens (new records). Sakhalin Island, Korsakovsky District, "Laguna Busse" Nature Monument, vicinity of Vyselkovoe Lake, 46³4'07.3"N 14315'08.2"E, alt. $9 \mathrm{~m}$, Picea-Larix forest on the edge of the swamp, on bark of Picea sp., 25.05.2017, leg. L.A. Konoreva (257).

\section{Cladonia stygia (Fr.) Ruoss}

Contributors: Evgeny A. Davydov \& Sergey Chesnokov

Distribution and habitat. Inhabits soil. In other regions it occurs on soils in tundra, wet bogs and upland woodland; widely distributed from the Arctic to forest zone, in the mountain, alpine and forest belts; RFE: Kam (Himelbrant et al. 2014, 2019) and Mag (Zheludeva 2017). It is reported for the first time for Southern part of the Russian Far East.

Taxonomical notes. This species belongs to Cladonia arbuscula group that is characterized by absence of cortex on podetia and its numerous branching. This species is closely related to Cladonia rangiferina (L.) F.H. Wigg. but distinguished by black podetial base, with starkly contrasting scattered white areoles and red pycnidial gel (Ahti \& Stenroos 2013).

Examined specimens (new records). Sakhalin Island, vicinity of Yuzhno-Sakhalinsk, Susunaysky Range, Chekhov

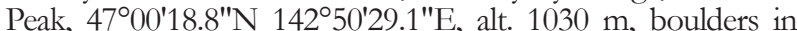
Pinus pumila thickets, on soil, 28.06.2017, leg. S.V. Chesnokov (240); Korsakovsky District, Maiorskaya Mt., 2.65 km NW Izvestkovyi Settlement, the headwaters of the Znamenka River, $46^{\circ} 54^{\prime} 13^{\prime \prime} \mathrm{N} 142^{\circ} 55^{\prime} 30^{\prime \prime} \mathrm{E}$, alt. $920 \mathrm{~m}$, SE slope, near the top, thickets of Pinus pumila, 6.08.2019, leg. E.A. Davydov (18051); Smirnyhovsky District, Vaida Mt., N slope, the headwaters of the Vitnitsa River, left bank, $47 \mathrm{~km}$ to E from the Smirnyh Settlement, $49^{\circ} 52^{\prime} 50^{\prime \prime} \mathrm{N} 143^{\circ} 28^{\prime} 04^{\prime \prime} \mathrm{E}$, alt. $680 \mathrm{~m}$, mountain tundra, on soil, 11.08.2019, leg. E.A. Davydov (18052).

\section{COLLEMATACEAE Zenker}

Scytinium subtile (Schrad.) Otálora et al.

Contributor: Liudmila Konoreva

Distribution and habitat. Inhabits bark of Salix sp. In other regions it prefers rotten wood of old, usually 
fallen trees, stumps, polypore fungi, and plant debris on the ground. It is scattered distributed from the Arctic to temperate regions, RFE: Pri (Chabanenko 2002) and Chu (Andreev et al. 1996). It is reported for the first time for Sakhalin.

Taxonomical notes. The genus Scytinium (Ach.) Gray was resurrected by Otálora et al. (2014). Currently this genus includes some small-sized species from large genus Leptogium (Ach.) Gray with pseudocortex instead true cortex. The most characteristic trait of Scytinium subtile is the globular, fisheye-like apothecia, which readily differs it from the larger S. tenuissimum (Dickson) Otálora et al. which has larger, urceolate apothecia and marginally lacerated squamules (Jørgensen 2007).

Examined specimens (new records). Sakhalin Island, Korsakovsky District, "Laguna Busse" Nature Monument, vicinity of Vyselkovoe Lake, 46³4'15.8"N 14315'30.2"E, alt. $11 \mathrm{~m}$, Salix forest near the road, on bark of Salix sp., 25.05.2017, leg. L.A. Konoreva (248).

\section{CONIOCYBACEAE Rchb.}

\section{Chaenotheca hispidula (Ach.) Zahlbr.}

Contributor: Sergey Chesnokov

Distribution and habitat. Found on bark of rotten Abies sachalinensis. In other regions it also occurs on bark of old Quercus spp., Alnus spp. and Salix spp. in shaded conditions. It is scattered distributed in temperate areas; SIB: Bur (Kharpukhaeva 2017) and Kra (Zhdanov 2014). It is reported for the first time for the Russian Far East.

Taxonomical notes. It is characterized by the rather short yellow-pruinose ascomata, the large globose spores and by having Trentepoblia as photobiont (Tibell 1999).

Examined specimens (new records). Sakhalin Island, Korsakovsky District, "Laguna Busse" Nature Monument, vicinity of Vyselkovoe Lake, $46^{\circ} 33^{\prime} 56.8^{\prime \prime} \mathrm{N} 143^{\circ} 16^{\prime} 50.5^{\prime \prime E}$, alt. $19 \mathrm{~m}$, Picea-Abies forest with Ledum sp., on bark of rotten Abies sachalinensis, 25.05.2017, leg. S.V. Chesnokov (120).

\section{FUSCIDEACEAE Hafellner}

\section{Fuscidea austera (Nyl.) P. James}

Contributors: Evgeny A. Davydov \& Lidia Yakovchenko

Distribution and habitat. Inhabits rock. In other regions it occurs on sheltered vertical siliceous rocks. It is scatterly distributed in the Arctic and in alpine belt in mountains; RFE: Pri (Cherdantseva et al. 2013). It is reported for the first time for Sakhalin.

Taxonomical notes. It is characterized by large (up to $2(-3.5) \mathrm{mm}$ wide), sessile, markedly constricted at the base, often conglomerate apothecia which take on a distinctive red-brown when moistened with flexuous margins, often convoluted and proliferous. Medulla I-, UV-. Divaricatic acid presents in apothecia only. Closely related F. taeniarum (Malme) V. Wirth \& Yezda is considering as a morph of F. austera with discrete and non-pruinose apothecia because it is linked with typical $F$. austera through transitional stages (Smith et al. 2009).

Examined specimens (new records). Sakhalin Island, Makarovsky District, Zhdanko Ridge, 4805'25"N 142³1'52"E, alt. $440 \mathrm{~m}$, rock NW exposition, near the watershed among meadow communities, on top of stone, 14.08.2019. leg. E.A. Davydov $(18015,18018)$.

\section{Fuscidea submollis Mas. Inoue}

Contributors: Evgeny A. Davydov \& Lidia Yakovchenko

Distribution and habitat. Found on rock. In other regions it occurs on siliceous rocks. It is scatterly distributed in the mountain in alpine belt. This record is the third in
Russia. Previously, the species was discovered in SIB: Bai (Chesnokov et al. 2018) and RFE: Pri (Yakovchenko et al. 2019). It is reported for the first time for Sakhalin.

Taxonomical notes. It differs from closely related Fuscidea mollis (Wahlenb.) V. Wirth \& Vězda by appressed apothecia, verrucose-areolate thallus and amyloid medulla.

Examined specimens (new records). Sakhalin Island, Korsakovsky District, Maiorskaya Mt., 2.9 km NW Izvestkovyi Settlement, the headwaters of the Znamenka River, $46^{\circ} 54^{\prime} 24^{\prime \prime} \mathrm{N} 142^{\circ} 55^{\prime} 40^{\prime \prime} \mathrm{E}$, alt. $960 \mathrm{~m}$, near the top, rock pillar, on rocks 06.08.2019, leg. E.A. Davydov (18001).

\section{LECANOGRAPHACEAE Ertz et al. \\ Alyxoria culmigena (Libert) Ertz}

Contributors: Liudmila Konoreva \& Sergey Chesnokov

Distribution and habitat. Inhabits bark of Picea sp. and Taxus cuspidata in coniferous forest. In other regions it also occurs on bark, wood, rarely occurs on sandstone, often in shaded conditions. It is widely distributed in boreal and temperate regions; RFE: Kam (Neshataeva et al. 2005). It is reported for the first time for southern part of the Russian Far East.

Taxonomical notes: The species was belonging to the genus Opegrapha Ach. until recently. The genus Alyxoria Ach. was reinstated by Ertzand Tehler (2011) basing on phylogenetic studies to accommodate the species of Opegrapha varia group characterized by Varia-type ascus. Moreover, species of this group have epruinose to pruinose ascomata with usually exposed hymenial disc. Alyxoria culmigena is distinguished from closely related species of this group by transversely 3 -septate ascospores, the wall is not swollen at the septa (Subelevata-type) and erythrin and lecanoric acid as thallus compounds (Joshi et al. 2015).

Examined specimens (new records). Sakhalin Island, Korsakovsky District, "Laguna Busse" Nature Monument, Arakul' River, $300 \mathrm{~m}$ to east of Vyselki tract, 46 $34^{\prime} 19^{\prime \prime N}$ 14314'03.6"E, alt. $9 \mathrm{~m}$, Picea-Abies-Larix forest with Ilex sp., on bark of Picea sp., 25.05.2017, leg. L.A. Konoreva (260); ibid., vicinity of Busse Lake, 46 $34^{\prime} 06.7^{\prime \prime} \mathrm{N}$ 1431'04.3"E, alt. $19 \mathrm{~m}$, Abies-Picea forest with Larix sp. and Taxus cuspidata, on bark of Taxus cuspidata, 26.05.2017, leg. S.V. Chesnokov (128).

\section{LECANORACEAE Körb.}

\section{Lecanora cinereofusca $\mathrm{H}$. Magn.}

Contributors: Liudmila Konoreva \& Sergey Chesnokov

Distribution and habitat. Inhabits bark of Sorbus sp. and Abies sachalinensis. In other regions it occurs on bark of Betula spp. and Salix spp. It is scattered distributed in the forest zone; RFE: Pri (Tchabanenko 2002, Skirina 2015b). It is reported for the first time for Sakhalin and Iturup Islands.

Taxonomical notes. This species belongs to Lecanora subfusca group. It is characterized by the presence of pannarin, immersed young apothecia with reddish disc and strongly crenulate to partly disappearing apothecial margin (MalíCek 2014). Lecanora pulicaris (Pers.) Ach. differs by a smooth apothecial margin, sessile apothecia and presence of fumarprotocetraric acid.

Examined specimens (new records). Iturup Island, Ostrovnoy Reserve, neighborhood of Iodny Cape, $44^{\circ} 43^{\prime} 40.3^{\prime \prime N} 147^{\circ} 19^{\prime} 41.2^{\prime \prime E}$, alt. $67 \mathrm{~m}$, Salix-Betula forest with Saza kurilensis along the old road, on bark of Salix sp. 16.08.2017, leg. L.A. Konoreva (643); Sakhalin Island, Korsakovsky District, "Laguna Busse" Nature Monument, between Vyselkovoe Lake and Laguna Busse, 46⒊'31.1"N $143^{\circ} 16^{\prime} 55.5^{\prime \prime E}$, alt. $12 \mathrm{~m}$, Abies-Larix-Picea forest swamped, on 
bark of Abies sachalinensis, 26.05.2017, leg. S.V. Chesnokov (125); ibid., vicinity of Busse Lake, 46 $34^{\prime} 07^{\prime \prime N} 143^{\circ} 18^{\prime} 44.8^{\prime \prime E}$, alt. 20 $\mathrm{m}$, Abies-Picea forest with Larix sp. and Pinus pumila, on bark of Sorbus sp., 24.05.2017, leg. L.A. Konoreva (242).

\section{Lecanora polytropa (Ehrh. ex Hoffm.) Rabenh.}

Contributors: Evgeny A. Davydov, Lidia Yakovchenko \& Sergey Chesnokov

Distribution and habitat. Inhabits siliceous rocks. In other regions it occurs on siliceous rocks and walls and worked timber. It is widely distributed from the Arctic to temperate regions; RFE: Kha (Yakovchenko et al. 2013, Tchabanenko 2002), Pri (Cherdantseva et al. 2013), Kam (Himelbrant et al. 2014, 2019), and Mag (Kotlov 1995). It is reported for the first time for Sakhalin.

Taxonomical notes. This species belongs to L. polytropa group included crustose species with green to yellow thallus containing usnic acid and/or xanthones, or calycin, and with generally pale yellow, often rather convex apothecia (Smith et al. 2009, Yakovchenko et al. 2019). It differs from the closely related species of $L$. intricata group by inconspicuous to granular thallus consisting of dispersed, convex areoles, not lobed or crenulate; and apothecial discs usually remaining yellowish or yellow-green, never becoming blackish.

Examined specimens (new records). Sakhalin Island, Korsakovsky District, vicinity of Yuzhno-Sakhalinsk, Susunaysky Range, Chekhov Peak, 4659'48.8"N 14250'06.8"E, alt. $977 \mathrm{~m}$, rocks, on stone, 28.06.2017, leg. S.V. Chesnokov (231); ibid., Borodavka rock pillar, N and W side, 46 $59^{\prime} 27^{\prime \prime} \mathrm{N}$ 142 50'18"E, alt. 910 m, 08.08.2019, leg. E.A. Davydov (18055); ibid., Korsakovsky District, Maiorskaya Mt., 2.9 km NW Izvestkovyi Settlement, the headwaters of the Znamenka River, $46^{\circ} 54^{\prime} 24^{\prime \prime} \mathrm{N} 142^{\circ} 55^{\prime} 40^{\prime \prime} \mathrm{E}$, alt. $960 \mathrm{~m}$, near the top, rock pillar, on stone, 06.08.2019, leg. E.A. Davydov (18057); Makarovsky District, Zhdanko Ridge, $48^{\circ} 05^{\prime} 49^{\prime \prime} \mathrm{N} 142^{\circ} 41^{\prime} 41.5^{\prime \prime E}$, alt. 380 $\mathrm{m}$, rock $\mathrm{W}$ exposition, among the Betula ermanii forest, on top of stone, 14.08.2019. leg. E.A. Davydov (18056); ibid., $48^{\circ} 05^{\prime} 25^{\prime \prime} \mathrm{N} 142^{\circ} 31^{\prime} 52^{\prime \prime} \mathrm{E}$, alt. $440 \mathrm{~m}$, rock NW exposition, near the watershed among meadow communities, on top of stone, 14.08.2019, leg. E.A. Davydov (18058).

\section{Lecanora sulphurea (Hoffm.) Ach.}

Contributors: Evgeny A. Davydov \& Lidia Yakovchenko

Distribution and habitat. Inhabits siliceous rock. In other regions occurs on exposed, somewhat nutrient-rich, siliceous rocks and walls. It is scattered distributed in the mountains and in the xeric-supralittoral on the coast; RFE: Kha (Yakovchenko et al. 2013). It is reported for the first time for Sakhalin.

Taxonomical notes. Like the previous one, this species belongs to $L$. polytropa group. It differs from other yellowgreen, saxicolous, non-sorediate species (for example L. atrosulphurea (Wahlenb.) Ach.) by chemical tests: thallus $\mathrm{C}-, \mathrm{K} \pm$ yellow-brown, $\mathrm{KC}+$ yellow, $\mathrm{Pd}-, \mathrm{UV}+$ dull orange (Smith et al. 2009).

Examined specimens (new records). Sakhalin Island, Korsakovsky District, vicinity of Yuzhno-Sakhalinsk, Susunaysky Range, Chekhov Peak, Borodavka rock pillar, N and $\mathrm{W}$ side, $46^{\circ} 59^{\prime} 27^{\prime \prime} \mathrm{N} 142^{\circ} 50^{\prime} 18^{\prime \prime} \mathrm{E}$, alt. $910 \mathrm{~m}$, on rocks, 08.08.2019, leg. E.A. Davydov (18094).

\section{Lecidella carpathica Körb.}

Contributors: Evgeny A. Davydov \& Lidia Yakovchenko

Distribution and habitat. Found on stone. In other regions it occurs basic, nutrient-enriched rocks and worked timber, often coastal. It is widely distributed species but probably overlooked; RFE: Chu (Savicz \& Elenkin 1950). It is reported for the first time for southern part of the Russian Far East.
Taxonomical notes. Lecidella is separated from Lecidea by the non-carbonaceous, brown-black exciple often pale inside, Lecanora-type asci and chemistry which includes a preponderance of xanthones making the thallus react $\mathrm{C}+$ orange. The close related genus Pyrrhospora Körb. belongs to the Lecanoraceae on the basis of the ascus structure, even though no thalline exciple is present (necessarily present in Lecidella spp.) (Smith et al. 2009). The semi-opaque, bright red-brown hypothecium and interior of the exciple distinguish L. carpatbica from L. stigmatea (Ach.) Hertel \& Leuckert. Buellia spuria (Schaer.) Anzi resembles L. carpatbica in habit but has brown, one-septate ascospores.

Examined specimens (new records). Sakhalin Island, Smirnyhovsky District, Vaida Mt., N slope, the headwaters of the Vitnitsa River, left bank, $47 \mathrm{~km}$ to E from the Smirnyh Settlement, $49^{\circ} 52^{\prime} 49^{\prime \prime} \mathrm{N} 143^{\circ} 28^{\prime} 00^{\prime \prime} \mathrm{E}$, alt. $700 \mathrm{~m}$, mountain tundra, on stone, 11.08.2019, leg. E.A. Davydov (18035).

\section{Rhizoplaca melanophthalma (DC.) Leuckert \& Poelt \\ Contributor: Sergey Chesnokov}

Distribution and habitat. Inhabits siliceous rocks. In other regions it occurs on rocks, usually calcium-low (e.g., basalt, granite, schist), but sometimes on calcium-rich sandstone or even on limestone; usually on exposed and often somewhat nutrient-enriched surfaces. It has a wide distribution from the Arctic to temperate regions, in the mountains, in alpine belt; RFE: Kha (Yakovchenko et al. 2013), Kam (Himelbrant et al. 2014), and Jew (Skirina 2015a). It is reported for the first time for Iturup Island.

Taxonomical notes. The genus Rhizoplaca Zopf is distinguished from the closely related Lecanora Ach. by lacking of distinctly radiating marginal lobes, loose medulla and welldeveloped lower cortex. From similar species of the genus Rhizoplaca with squamulose to umbilicate thallus $R$. melanophtalma is distinguished by distinct bluish black tinges on the margins (in contrast to $R$. subdiscrepans (Nyl.) R. Sant.); upper surface usually relatively deep yellowish green to olive or brownish and absence of cortical substances other than usnic acid (in contrast to $R$ chrysoleuca $(\mathrm{Sm}$.) Zopf and $R$. subdiscrepans); absence of terpenoids in the medulla (in contrast to R. peltata (Ramond) Leuckert \& Poelt) (Ryan 2002).

Examined specimens (new records). Iturup Island, Ostrovnoy Reserve, neighborhood of Iodny Cape, 44²43'15.4"N $147^{\circ} 21^{\prime} 15^{\prime \prime E}$, alt. $1 \mathrm{~m}$, rocks on the shore of the Pacific Ocean, on stone, 16.08.2017, leg. S.V. Chesnokov (291).

\section{LECIDEACEAE Chevall.}

\section{Amygdalaria panaeola (Ach.) Hertel \& Brodo}

\section{Contributor: Liudmila Konoreva}

Distribution and habitat. Inhabits rocks. In other regions it also occurs on siliceous rocks especially near the lakes and sea coasts. It is scatterly distributed in the Arctic and mountains; RFE: Kam (Himelbrant et al. 2019), Chu (Andreev et al. 1996), Mag (Kotlov 1995), Yak (Poryadina 2005), Pri (Zhdanov 2014, Yakovchenko et al. 2019); Kha (Yakovchenko et al. 2013). It is reported for the first time for Sakhalin.

Taxonomical notes. The genus Amygdalaria Norman includes 14 crustose saxicolous lichens with cephalodia distributed only in Northern Hemispere. Amygdalaria panaeola is distinguished from other species of the genus currently known from Russia by the thallus with soralia.

Examined specimens (new records). Sakhalin Island, vicinity of Yuzhno-Sakhalinsk, Susunaysky Range, Chekhov Peak, 4700'20.6"N 14250'24.6"E, alt. 1042 m, boulders in Pinus pumila thickets, on stone, 28.06.2017, leg. L.A. Konoreva (508). 


\section{Lecidea lapicida (Ach.) Ach.}

Contributors: Evgeny A. Davydov \& Lidia Yakovchenko

Distribution and habitat. Inhabits siliceous rocks. In other regions it occurs on siliceous, sometimes iron-rich, rocks. It is widely distributed especially in the Arctic and mountain areas; RFE: Kha (Yakovchenko et al. 2013), Amu (Pchelkin 2008), Pri (Tchabanenko 2002), Jew (Skirina 2015a), Kam (Hertel \& Andreev 2003, Himelbrant et al. 2014). It is reported for the first time for Sakhalin.

Taxonomical notes. Due to black lecideoid apothecia and pale crustose epilithic thallus the representatives of Lecidea Ach. might be mistaken with species of Porpidia Körb. Comments on the characteristic features of the genus Porpidia and differences between these genera are noted in the description of $P$. bydrophila. The main characters are Lecideatype of ascus apices structure and absence of halo in young ascospores. This species belongs to widespread L. lapicida group. L. lapicida differs from L. lapicida var. pantherina Ach. only chemically (predominance of norstictic acid in L. lactea versus lack of it in L. lapicida. From L. confluens (Weber) Ach. it differs by absence of confluentic acid and paler thallus. L. lapicida has the same medulla reactions as L. praenubila Nyl. but a paler and not glossy thallus. Lecidea plana (J. Lahm) Nyl. differs from L. lapicida in having the yellow-grey exciple and I- medulla instead dark green exciple and I+medulla in L. lapicida (Smith et al. 2009).

Examined specimens (new records). Sakhalin Island, Korsakovsky District, Maiorskaya Mt., 2.9 km NW Izvestkovyi Settlement, the headwaters of the Znamenka River, $46^{\circ} 54^{\prime} 24^{\prime \prime} \mathrm{N} 142^{\circ} 55^{\prime} 40^{\prime \prime} \mathrm{E}$, alt. $960 \mathrm{~m}$, near the top, rock pillar, on stone, 06.08.2019, leg. E.A. Davydov (18002).

\section{Porpidia hydrophila (Fr.) Hertel \& A.J. Schwab}

Contributors: Evgeny A. Davydov \& Lidia Yakovchenko

Distribution and habitat. Inhabits rocks near the headwaters of the river. In other regions it occurs on inundated siliceous rocks by upland streams and lakes. It is scatterly distributed in the mountain and in alpine belt; SIB: Bur (Kharpukhaeva 2013, 2015). It is reported for the first time for the Russian Far East.

Taxonomical notes. Genus Porpidia is difficult for the identification, and there are a lot of closely related genera distinguished only by structure of ascus apex, for example Lecidea s. str. Ascus apices of Porpidia-type is characteristic for this genus (it can be seen only in microscope when processing of apothecia cross-section by I). But also there are a lot of saxicolous genera with similar ascus type (for example, Bellemerea Hafellner \& Cl. Roux, Clauradea Hafellner \& Bellem., Farnoldia Hertel, Immersaria Rambold \& Pietschmann, Koerberiella Stein etc.). Their differences from the genus Porpidia are described in detail in the literature (Rambold 1989, Smith et al. 2009). Porpidia bydriphila is mostly distinguished from other species of the genus by thick (up to $25 \mu \mathrm{m}$ ) blue-green epithecium.

Examined specimens (new records). Sakhalin Island, Korsakovsky District, Maiorskaya Mt., 2.9 km NW Izvestkovyi Settlement, the headwaters of the Znamenka River, $46^{\circ} 54^{\prime} 24^{\prime \prime N} 142^{\circ} 55^{\prime} 40^{\prime \prime} \mathrm{E}$, alt. $960 \mathrm{~m}$, near the top, rock pillar, on stone, 06.08.2019, leg. E. A. Davydov (18027, 18029).

\section{Porpidia macrocarpa (DC.) Hertel \& A.J. Schwab}

Contributors: Evgeny A. Davydov \& Lidia Yakovchenko

Distribution and habitat. Inhabits siliceous rocks. In other regions it occurs on exposed siliceous rocks and large boulders, less often on pebbles and loose stones, rarely on wood and bark. It is a widely distributed species especially in the mountains; RFE: Pri (Cherdantseva et al. 2013, Skirina 2015b), Kha (Yakovchenko et al. 2013), Jew (Skirina 2015a), Kam (Himelbrant et al. 2014, 2019), and Mag (Kotlov 1995). It is reported for the first time for Sakhalin.

Taxonomical notes. P. macrocarpa is extremely variable species and taxonomical studies (Gowan 1989, Fryday 2005) have separated some distinctive taxa as species (e.g. P. fiavocruenta Fryday \& Buschbom, P. striata Fryday, $P$. thomsonii Gowan). P. macrocarpa differs from other species of the genus by insignificant thallus and large apothecia (up to $3 \mathrm{~mm}$ in diam.) with a thick tumid margin. Apothecia of close related P. crustulata (Ach.) Hertel \& Knoph are not exceeding of $1.5 \mathrm{~mm}$ in diam.; proper margin narrower, non-tumid $(<0.05 \mathrm{~mm}$ wide) (contrary 0.15-0.2 mm wide exciple in P. macrocarpa) (Smith et al. 2009).

Examined specimens (new records). Sakhalin Island, Smirnyhovsky District, Vaida Mt., NW slope, the headwaters of the Vitnitsa River, left bank, $47 \mathrm{~km}$ to E from the Smirnykh Settlement, 49 $52^{\prime} 49^{\prime \prime} \mathrm{N} 143^{\circ} 28^{\prime} 00^{\prime \prime} \mathrm{E}$, alt. $700 \mathrm{~m}$, karst funnel on the $\mathrm{N}$ slope, on stone, $\mathrm{N}$ exposure, 11.08.2019, leg. E.A. Davydov (18034).

\section{MYCOBLASTACEAE Hafellner Mycoblastus affinis (Schaer.) T. Schauer}

Contributor: Sergey Chesnokov

Distribution and habitat. Found on bark of Abies sachalinensis. In other regions it occurs on acidic bark, especially conifer or Betula ssp., less frequently overgrowing mosses on rock, rarely directly on rock in well-wooded places. It is scattered distributed from the Arctic to forest zones, in alpine and forest belt in the mountains; RFE: Kha (Velikanov \& Skirina 2012), Pri (Skirina 2015b), and Kam (Himelbrant et al. 2014). It is reported for the first time for Iturup Island.

Taxonomical notes. The number of species of genus Mycoblastus Norman and its taxonomic position are discussed up to now because of heterogeneity of genus. Some species of this genus may demonstrate affinity with the family Megalariaceae and the genus Japewia Tønsberg (Kantvilas 2009). It differs from M. sanguinarius (L.) Norman by the pale base to the apothecia and 2-spored asci. The separation of Mycoblastus affinis and M. alpinus (Fr.) Th. Fr. ex Hellb. needs further study.

Examined specimens (new records). Iturup Island, Ostrovnoy Reserve, vicinity of Lesozavodskoy settlement, $44^{\circ} 45^{\prime} 51.2^{\prime \prime} \mathrm{N} 147^{\circ} 11^{\prime} 13.3^{\prime \prime} \mathrm{E}$, alt. $10 \mathrm{~m}$, stony lava shore with fir forest, on bark of Abies sachalinensis, 14.08.2017, leg. S.V. Chesnokov (266).

\section{MYCOCALICIACEAE A.F.W. Schmidt Chaenothecopsis debilis (Sm.) Tibell \\ Contributor: Sergey Chesnokov}

Distribution and habitat. Found on bark of rotten Abies sachalinensis. In other regions it also occurs on dry wood, rarely bark of coniferous and deciduous trees, in open dry plant communities. It is widely distributed from the boreal forests to subtropical zone; the nearest locations in the RFE: Jew (Skirina 2015a); Kam, Kha and Pri (Titov 2006). It is reported for the first time for Sakhalin.

Taxonomical notes. It is characterized by 1 -septated, smooth, medium-brown spores with distinct septum. Epithecium and excipulum are reddish brown, hypothecium is greenish or brownish, stalk $\mathrm{HNO} 3+$ red-violet. It differs from Chaenothecopsis transbaikalica Titov and C. sanguinea Tibell by its $\mathrm{HNO}_{3}+$ red-violet reaction of the stalk; from C. pusilla (Ach.) A.F.W. Schmidt - by asci length [C. debilis - (35-) $44.6-$ $50.4(-55) \mu \mathrm{m}$, C. pusilla - (28.0-) 29.4-38.2 (-40.5) $\mu \mathrm{m}]$ and more contrast septum. Closely related C. vainioana (Nádv.) Tibell is distinguished by the reaction of stalk with $\mathrm{HNO}_{3}$ (red colored upper layer of stalk intensifying) (Titov 2006). 
Examined specimens (new records). Sakhalin Island, Korsakovsky District, "Laguna Busse" Nature Monument, vicinity of Vyselkovoe Lake, 46³ $33^{\prime} 56.8^{\prime \prime} \mathrm{N} 143^{\circ} 16^{\prime} 50.5^{\prime \prime} \mathrm{E}$, alt. $19 \mathrm{~m}$, Picea-Abies forest with Ledum sp., on bark of rotten Abies sachalinensis, 25.05.2017, leg. S.V. Chesnokov (120).

\section{PARMELIACEAE Zenker \\ Hypogymnia subobscura (Vain.) Poelt \\ Contributor: Sergey Chesnokov}

Distribution and habitat. Fount on soil. In other regions it occurs on soils and mosses on the ground in tundra. It is scatterly distributed in Arctic and in mountains in alpine belt; RFE: Mag (Korolev \& Tolpysheva 1980), Kam (Himelbrant et al. 2014, 2019), Kha (Yakovchenko et al. 2013), and Pri (Skirina 2015b). It is reported for the first time for Sakhalin.

Taxonomical notes. The taxonomical status of this species is defined differently by systematics. Øvstedal et al (2009) consider this species in scope of Hypogymnia austerodes (Nyl.) Räsänen. Westberg et al. (2011) designate this species as separated taxa differed in having papillae never breaks up into soralia and by chemistry.

Examined specimens (new records). Sakhalin Island, vicinity of Yuzhno-Sakhalinsk, Susunaysky Range, Chekhov Peak, 4659'26.8"N 14250'18.1"E, alt. 909 m, rocks among Pinus pimula and Betula ermanii, on soil, 28.06.2017, leg. S.V. Chesnokov (243).

\section{Melanelixia glabratula (Lamy) Sandler \& Arup \\ Contributor: Sergey Chesnokov}

Distribution and habitat. Inhabits bark of Abies sachalinensis. In other regions it occurs on bark of broad-leaved trees, rarely grows on conifers, lignin or on siliceous stones. It is widely distributed in the temperate regions; RFE: Jew (Skirina 2015a) and Amu (Tolpysheva \& Zhiryakova 1988). It is reported for the first time for Iturup Island.

Taxonomical notes. The brown parmelioid lichens were classified in genus Melanelia Essl. up to 2004, when it was revised using molecular methods (Blanco et al. 2004). As a result, the new genus Melanelixia O. Blanco was described. At present, it includes 8 species and is characterized by having a pored or fenestrate epicortex, lacking pseudocyphellae and containing lecanoric acid as the primary medullary constituent (Blanco et al. 2004). M. glabratula is considered for a long time as intraspecific taxa in $M$. fuliginosa (Fr. ex Duby) O. Blanco et al. and was segregated recently (Arup \& Berlin 2011). It differs from $M$. fuliginosa by paler, olivaceous green to brown color and the corticolous habit. It may be confused with indistinctly sorediate specimens of $M$. subaurifera $(\mathrm{Nyl}$.) $\mathrm{O}$. Blanco et al., but is recognized by the presence of orange pigment in patches in medulla (Westberg \& Thell 2011a).

Examined specimens (new records). Iturup Island, Ostrovnoy Reserve, vicinity of Lesozavodskoy settlement, $44^{\circ} 45^{\prime} 51.2^{\prime \prime} \mathrm{N}, 147^{\circ} 11^{\prime} 13.3^{\prime \prime} \mathrm{E}$, alt. $10 \mathrm{~m}$, rocky side of lava flow with fir forest, on bark of Abies sachalinensis, 14.08.2017, leg. S.V. Chesnokov $(265,266)$.

\section{Melanohalea exasperata (De Not.) O. Blanco et al. \\ Contributor: Liudmila Konoreva}

Distribution and habitat. Found on bark of Betula ermanii. In other regions it occurs on acidic bark of broadleaved trees, sometimes lignum and rocks in well-lit sites. It is widely distributed in the cold and temperate regions, in Asia rarer than in Europe; RFE: Pri and Kha (Tchabanenko 2002, Skirina 2015b). It is reported for the first time for Iturup Island.

Taxonomical notes. The genus Melanohalea O. Blanco et al. was segregated by Blanco and co-authors (2004) from the genus Melanelia and is characterized by pseudocyphellae, usually on warts or isidial tips, a non-pored epicortex, and a medulla containing depsidones or lacking secondary compounds. Now it includes 19 species. M. exasperata is distinguished by broadbased papillae (isidia) on the upper surface of thallus and on the apothecia margins (Westberg \& Thell 2011b).

Examined specimens (new records). Iturup Island, Ostrovnoy Reserve, neighborhood of Iodny Cape, $44^{\circ} 43^{\prime} 22^{\prime \prime N}$ $147^{\circ} 20^{\prime} 53.3^{\prime \prime E}$, alt. $15 \mathrm{~m}$, Salix-Alnus forest along the old road, on bark of Betula ermanii, 17.08.2017, leg. L.A. Konoreva (665).

\section{Nephromopsis nephromoides (Nyl.) Ahti \& Randlane \\ Contributor. Sergey Chesnokov}

Distribution and habitat. Found on bark of coniferous trees. In Russia this species was found only in the south of Far East in Primorye Territory (Tchabanenko 2002, Skirin \& Skirina 2012, Skirina 2017). It is reported for the first time for Kunashir Island.

Taxonomical notes. This species may be confused with Nephromopsis laii (A. Thell \& Randlane) Saag \& A. Thell. which however has small and flat pseudocyphellae situated mainly on the brown coloured ridges of the generally paler lower surface, while pseudocyphellae of $N$. nephromoides are medium to large, flat or concave and developed directly on the surface (Randlane \& Saag 2001).

Examined specimens (new records). Kunashir Island, Tret'yakovo, to the S from Yuzhno-Kurilsk Sity, on bark of coniferous tree, 20.09.1989, leg. L.I. Bredkina (LE).

\section{PHYSCIACEAE Zahlbr.}

\section{Physcia caesia (Hoffm.) Fürnr.}

\section{Contributor: Sergey Chesnokov}

Distribution and habitat. Inhabits rocks on the sea coast. In other regions it occurs on well-lit, nutrient-rich, basic substrata, including tops of walls, calcareous rocks, rarely on siliceous rocks, especially in coastal districts or boulders in or by upland streams and lake margins, sometimes on timberwork and tree bases. It is widely distributed in all regions; RFE: Pri (Tchabanenko 2002, Skirina 2015b), Kha (Tchabanenko 2002), Jew (Skirina 2015a), Kam (Himelbrant et al. 2014, 2019), Mag (Kotlov 1995), Amu (Pchelkin 2008). It is reported for the first time for Iturup Island.

Taxonomical notes. Genus Physcia (Schreb.) Michx. includes widely distributed species with rosette-like gray thallus and paraplectinchymatous upper cortex with constantly presence of atranorin (K+yellow reactions) (Moberg 2002). From $P$. dubia (Hoffm.) Lettau it differs by $\mathrm{K}+$ yellow reaction of medulla ( $\mathrm{K}-$ in P. dubia); from P. tribacoides $\mathrm{Nyl}$. by the characters of soralia (capitate in P. caesia) and maculae upper cortex; from P. subalbinea Nyl. by capitate soralia (lipshaped in P. subalbinea) (Urbanavichene 2008).

Examined specimens (new records). Iturup Island, Ostrovnoy Reserve, neighborhood of Iodny Cape, $44^{\circ} 43^{\prime} 15.4^{\prime \prime} \mathrm{N}$ $147^{\circ} 21^{\prime} 15^{\prime \prime} \mathrm{E}$, alt. $1 \mathrm{~m}$, rocks on the shore of the Pacific Ocean, on stone, 16.08.2017, leg. S.V. Chesnokov (291).

\section{Physcia dubia (Hoffm.) Lettau}

Contributor: Liudmila Konoreva

Distribution and habitat. Inhabits bark of deciduous tree. In other regions it occurs on non-calcareous rocks and building materials in well-lit, nutrient-rich situations, e.g. roofs, bird-perch stones; occasional on timberwork and bark. It is widely distributed in all regions; RFE: Kam (Himelbrant et al. 2014, 2019), Mag (Zheludeva 2015), Pri (Tchabanenko 2002, Skirina 2015b), Kha (Chabanenko 2002, Yakovchenko et al. 2013), Amu (Pchelkin 2008). It is reported for the first time for Sakhalin. 
Taxonomical notes. Physcia dubia is a variable species and certain modifications have been recognized as separate species (P. intermedia Vain. and P. teretiuscula (Ach.) Lynge) (Moberg 2002). From P. tenella (Scop.) DC. it differs by absence of cilia; from P. tribacia (Ach.) Nyl. by its multiple dichotomously branching marginal lobes, prosoplectenchymatous upper cortex and characters of soralia; from $P$. subalbinea by $\mathrm{K}$-reaction of the medulla $(\mathrm{K}+$ yellow in P. subalbinea) (Urbanavichene 2008).

Examined specimens (new records). Sakhalin Island, Yuzhno-Sakhalinsk, Sakhalin Botanical Garden, $46^{\circ} 56^{\prime} 40.1^{\prime \prime} \mathrm{N} 142^{\circ} 45^{\prime} 46.7^{\prime \prime E}$, alt. $135 \mathrm{~m}$, floodplain forest with Larix kurilensis and Caragana arborescens, on bark of Caragana arborescens, 07.05.2017, leg. L.A. Konoreva (1).

\section{PILOCARPACEAE Zahlbr.}

\section{Micarea nigella Coppins}

Contributor: Liudmila Konoreva

Distribution and habitat. Found on wood of Larix kurilensis. In other regions it occurs on growing wood almost always in rather moist, shaded conditions. Distribution in Russian part of Asia: Caucasus, Republic of Ingushetia (Urbanavichus \& Urbanavichene 2017a). It is reported for the first time for the Russian Far East.

Taxonomical notes. Micarea nigella is similar to M. contexta Hedl. but differs by simple smaller spores [M. contexta 1-septate and 7-12 $\times 3-4.5 \mu \mathrm{m}$ according to Czarnota (2011)]. No substances detected by HPTLC. Spot tests: green color of hymenium and epihymenium in $\mathrm{K} \pm$ green intensifying, $\mathrm{N}+$ red to purplish, $\mathrm{HCl}+$ blue-green ('Cinereorufa-green'). Dark purple color of hypothecium in $\mathrm{K}+$ green, $\mathrm{N}+$ red, $\mathrm{HCl}+$ purple ('Melaena-red').

Examined specimens (new records). Shikotan Island, neighborhood of Malaya Tserkovnaya Bay, $43^{\circ} 43^{\prime} 42^{\prime \prime} \mathrm{N}$ $146^{\circ} 40^{\prime 28.4 " E}$, alt. $66 \mathrm{~m}$, Larix kurilensis forest with Sasa kurilensis, on wood of Larix kurilensis Mayr, 13.06.2017, leg. L.A. Konoreva (314).

\section{RHIZOCARPACEAE M. Choisy \& Hafellner Rhizocarpon expallescens $\mathrm{Th}$. Fr.}

Contributors: Evgeny A. Davydov \& Lidia Yakovchenko

Distribution and habitat. Inhabits siliceous rocks. It is a scatterly distributed arcto-alpine species; RFE: Chu (Dobrysh \& Makarova 1998). It is reported for the first time for Southern part of the Russian Far East.

Taxonomical notes. This species belongs to the group of widely distributed genus Rhizocarpon Ramond ex DC. with white-gray-brown thallus (without yellow pigment in upper cortex). This species appears to be separated from R. caeruleoalbum (Kremp.) Zahlbr. only by the absence of stictic acid in the thallus and $\mathrm{K}+$ purple-red exciple (in contrast, $\mathrm{K}+$ yellow exciple in $\mathrm{R}$. caeruleoalbum). From $\mathrm{R}$. chioneum (Norman) Th. Fr. it differs in having bright green to blueblack K- epithecium (in contrast $\mathrm{K}+$ purple-red epithecium in $\mathrm{R}$. chioneum) (Smith et al. 2009).

Examined specimens (new records). Sakhalin Island, Makarovsky District, Zhdanko Ridge, $48^{\circ} 05^{\prime} 25^{\prime \prime} \mathrm{N}$ $142^{\circ} 31^{\prime} 52^{\prime \prime E}$, alt. $440 \mathrm{~m}$, rock NW exposition, near the watershed among meadow communities, rock SW exposure and NW slope, on top of stone, 14.08.2019. leg. E.A. Davydov $(18010,18017)$.

\section{Rhizocarpon hochstetteri (Körb.) Vain.}

Contributors: Evgeny A. Davydov \& Lidia Yakovchenko

Distribution and habitat. Inhabits exposed siliceous rock. It is widely distributed arcto-alpine species; RFE: Kam (Himelbrant et al. 2014) and Jew (Skirina 2015a). It is reported for the first time for Sakhalin.
Taxonomical notes. This species belongs to the group of widely distributed genus Rhizocarpon with white-graybrown thallus (without yellow pigment in upper cortex). Unlike other Rhizocarpon species with colourless, one-septate ascospores, those of $R$. hochstetteri are large $(21-25 \times$ $8.5-12 \mu \mathrm{m})$ and often become brown with maturity. The medulla is I-, (morphologically closely related $\mathrm{R}$. richardii (Lamy ex Nyl.) Zahlbr. and R. polycarpum (Hepp) Th. Fr. have I+ blue medulla) (Smith et al. 2009). R. infernulum (Nyl.) Lynge was included in $R$. hochstetteri, but this name was resurrected by Fryday (2002) for the species which has smaller ascospores $(17.5-19(-20) \times 8.5-11.0 \mu \mathrm{m})$.

Examined specimens (new records). Sakhalin Island, Makarovsky District, Zhdanko Ridge, $48^{\circ} 05^{\prime} 25^{\prime \prime} \mathrm{N}$ $142^{\circ} 31^{\prime} 52^{\prime \prime E}$, alt. $440 \mathrm{~m}$, rock NW exposition, near the watershed among meadow communities, on stone, 14.08.2019, leg. E.A. Davydov (18036).

\section{Rhizocarpon superficiale (Schaer.) Vain.}

Contributors: Evgeny A. Davydov \& Lidia Yakovchenko

Distribution and habitat. Inhabits siliceous rocks. In other regions it occurs on exposed siliceous rocks. It is scatterly distributed arcto-alpine species; RFE: Chu (Dobrysh \& Makarova 1998) and Yak (Poryadina 2005). It is reported for the first time for southern part of the Russian Far East.

Taxonomical notes. This species belongs to group of widely distributed genus Rhizocarpon with yellow pigment in upper cortex. The dark rim of the true exciple is often partly eroded, exposing a paler inner part and imparting a grey-white tone to the apothecial edge. This feature and the smaller ascospores $(12-20 \times 6-10 \mu \mathrm{m})$ differ the species from R. eupetraeoides (Nyl.) Blomb. \& Forssell (ascospores size: $22-34 \times 9-17 \mu \mathrm{m})$ which can also be $\mathrm{K}+$ red (Smith et al. 2009).

Examined specimens (new records). Sakhalin Island, Korsakovsky District, Maiorskaya Mt., 2.9 km NW Izvestkovyi Settlement, the headwaters of the Znamenka River, $46^{\circ} 54^{\prime} 24^{\prime \prime} \mathrm{N} 142^{\circ} 55^{\prime} 40^{\prime \prime} \mathrm{E}$, alt. $960 \mathrm{~m}$, near the top, rock pillar, on stone, 06.08.2019, leg. E. A. Davydov (18024).

\section{SCOLICIOSPORACEAE Hafellner \\ Scoliciosporum chlorococcum (Graeme ex Stenh.) Vězda}

Contributors: Sergey Chesnokov \& Liudmila Konoreva

Distribution and habitat. Inhabits bark of Betula sp., Alnus sp., Salix sp., wood of stump and bark of Larix kurilensis in the various type of forests. In other regions it can also inhabit bark, wood, plant debris and sometimes stone. It has a wide distribution from the Arctic to temperate regions; RFE: Amu (Pchelkin 2008), Kha (Yakovchenko et al. 2013), Pri (Skirina 2015b, 2017), Jew (Skirina 2015a), Kam (Himelbrant et al. 2014, 2019). It is reported for the first time for Sakhalin.

Taxonomical notes. The straighter ascospores differ this species from the otherwise similar Scoliciosporum sarothamni (Vain.) Vězda and S. umbrinum (Ach.) Arnold. Sterile specimens $S$. sarothamni with green thalli can be difficult to separate from more granular forms of $S$. chlorococcum but in such cases the contrasting pale yellow-green, $\mathrm{C}+$ red soralia of $S$. sarothamni from the overall uniform, C- colour of S. chlorococcum is diagnostic (Smith et al. 2009). Some sorediose morphs may be referable to the segregate species, S. gallurae Vězda \& Poelt.

Examined specimens (new records). Sakhalin Island, Yuzhno-Sakhalinsk, Sakhalin Botanical Garden, 4656'41.2"N $142^{\circ} 45^{\prime} 56.0^{\prime \prime E}$, alt. $108 \mathrm{~m}$, grass birch forest, on bark of Betula alba, 07.05.2017, leg. S.V. Chesnokov (4); ibid., 4656'40.1"N $142^{\circ} 45^{\prime} 46.7^{\prime \prime E}$, alt. $135 \mathrm{~m}$, floodplain forest with Larix kurilensis, 
on bark of Almus sp., 07.05.2017, leg. L.A. Konoreva (5); ibid., $46^{\circ} 56^{\prime} 40.7^{\prime \prime} \mathrm{N} 142^{\circ} 45^{\prime} 53.9^{\prime \prime} \mathrm{E}$, alt. $103 \mathrm{~m}$, stream in forest with alder, birch and willow, branch of Betula sp., 07.05.2017, leg. L.A. Konoreva (10); ibid., 4656'41.6"N 142 45'58.2"E, alt. 115 $\mathrm{m}$, Larix kurilensis windfall timber near the fence, on bark of Salix sp., 07.05.2017, leg. L.A. Konoreva (16); Sakhalin Island, Korsakovsky District, "Laguna Busse" Nature Monument, vicinity of Vyselkovoe Lake, 46 $34^{\prime} 12.1^{\prime \prime N} 143^{\circ} 15^{\prime} 00.5^{\prime \prime} \mathrm{E}$, alt. $9 \mathrm{~m}$, Larix woodland with Ledum sp. on a raised bog, on the stump of Larix kurilensis, 25.05.2017, leg. S.V. Chesnokov (115); ibid., 46 $34^{\prime} 07.3^{\prime \prime} \mathrm{N} 143^{\circ} 15^{\prime} 08.2^{\prime \prime} \mathrm{E}$, alt. $9 \mathrm{~m}$, Picea-Larix forest along the edge of the bog, on bark of Larix kurilensis, 25.05.2017, leg. S.V. Chesnokov (114).

\section{Scoliciosporum intrusum (Th. Fr.) Hafellner}

Contributors: Evgeny A. Davydov \& Lidia Yakovchenko

Distribution and habitat. Inhabits rocks. In other regions it also occurs on granites, calcium-rich stones and bark, sometimes it can inhabit crustose lichens, e.g. Lecidea spp., Rhizocarpon spp. It is scattered distributed in alpine belt of the mountains; RFE: Pri (Skirina 2010, 2017, Zhdanov 2014b). It is reported for the first time for Sakhalin.

Taxonomical notes. The new combination Scoliciosporum intrusum (Th. Fr.) Hafellner is introduced by Hafellner (2004), Carbonea intrusa (Th. Fr.) Rambold \& Triebel was synonymised with $S$. intrusum. As already mentioned by Coppins (1983) and Hinds et al. (2002), the habit of Scoliciosporum intrusum apothecia is exactly like in other Scoliciosporum A. Massal. species. Also the anatomical features of the apothecia i.e., the poorly developed, not carbonized exciple, the hyaline to weakly pigmented hypothecium, the richly branched and anastomosing paraphyses, the shape of the asci, and the construction of the ascal wall fit perfectly with Scoliciosporum. Unusual are the unicellular ascospores which may become one-septate with age. A certain tendency of the ascospores to be asymmetric indicates that the ascospores can be regarded as an extreme within the intrageneric continuum of Scoliciosporum (Hafellner 2004). Only two obligatorily lichenicolous Scoliciosporum species are known, S. vonauxii (de Lesd.) Hafellner (Hafellner 2002) and S. intrusum. While $S$. intrusum grows on a range of saxicolous crustose lichens inhabiting siliceous rocks, $S$. vouauxii has been found only on Ramalina Ach. in Luyken. It might be mistaken with Micarea subnigrata (Nyl.) Coppins \& H. Kilias which has a brown epithecium and a micareoid photobiont.

Examined specimens (new records). Sakhalin Island, Korsakovsky District, vicinity of Yuzhno-Sakhalinsk, Susunaysky Range, Chekhov Peak, Borodavka rock pillar, $\mathrm{N}$ and $\mathrm{W}$ side, $46^{\circ} 59^{\prime} 27^{\prime \prime} \mathrm{N}, 142^{\circ} 50^{\prime} 18^{\prime \prime} \mathrm{E}$, alt. $910 \mathrm{~m}$, 08.08.2019, on rock, leg. E.A. Davydov (18023).

\section{TELOSCHISTACEAE Zahlbr. \\ Caloplaca stillicidiorum (Vahl) Lynge}

Contributor: Liudmila Konoreva

Distribution and habitat. Inhabits wood. In other regions it occurs on plant debris and mosses, exposed wood of roots and rocks in calcareous xerothermic habitats. It is widely distributed from Arctic to aridic regions and in mountains; RFE: Kam (Khodosovtsev et al. 2004, Himelbrant et al. 2019). It is reported for the first time for southern part of the Russian Far East.

Taxonomical notes. This species belongs to Caloplaca cerina group and is distinguished from corticolous Caloplaca cerina s.l. by growing on / or near the ground on various substrata such as bryophytes, plant debris, wood, bark of exposed roots (Šoun et al. 2011).

Examined specimens (new records). Iturup Island, Ostrovnoy Reserve, neighborhood of Iodny Cape, Iodny vil- lage, $44^{\circ} 43^{\prime} 23.7^{\prime \prime} \mathrm{N} 147^{\circ} 21^{\prime} 31.5^{\prime \prime} \mathrm{E}$, alt. $30 \mathrm{~m}$, abandoned border settlement, on wood, 17.08.2017, leg. L.A. Konoreva (677).

\section{Polycauliona phlogina (Ach.) Arup et al.}

\section{Contributor: Sergey Chesnokov}

Distribution and habitat. Found on wood. In other regions it occurs on bark. There is a strong preference for a high pH, for example, bark of Ulmus spp., Fraxinus spp., and Acer spp. It is probably widely distributed species but needs further research due to difficulties in identification. In Russia, the species was known from the Leningrad Region (Stepanchikova et al. 2015, 2019, Vondrák et al. 2010a) and Krasnodar Territory (Vondrák et al. 2009, 2010b, 2017, Urbanavichus \& Urbanavichene 2017b). It is reported for the first time for the Asian part of Russia.

Taxonomical notes. Polycauliona phlogina is characterized by the mainly sorediate thallus with only occasionally small pale yellow to yellow areoles with contrasting orange-yellow apothecia. Sometimes it is sterile and very pale yellow or grey, and it may be difficult to separate it from an orangegrey form of Lepraria incana (L.) Ach. Leproplaca chrysodeta (Vain.) J.R. Laundon ex Ahti is another similar taxon that rarely occurs on bark. It differs by more brownish orange colour, leprose thallus, complete absence of areoles and apothecia, and a strong preference for humid places. Also Flavoplaca flavocitrina (Nyl.) Arup et al. has been mistaken with C. phlogina, but on bark it always has a large portion of the areoles not dissolved into soredia. Sometimes Coppinsiella ulcerosa (Coppins \& P. James) S. Y. Kondr. \& L. Lőkös is confused with P. phlogina, but it has small greenish grey soralia formed as irregular craters that become more diffuse in old specimens (Arup 2006).

Examined specimens (new records). Iturup Island, Os-

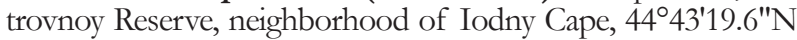
$147^{\circ} 21^{\prime} 17.2^{\prime \prime} \mathrm{E}$, alt. $5 \mathrm{~m}$, destroyed bridge, on wood, 17.08.2017, leg. S.V. Chesnokov (312)

\section{TRAPELIACEAE M. Choisy ex Hertel Placynthiella oligotropha (J.R. Laundon) Coppins \& P. James}

\section{Contributor: Sergey Chesnokov}

Distribution and habitat. Found on soil. In other regions it occurs on peaty soils and well-rotted lignum in open heathlands and woodland clearings, often around old stumps. It is scattered distributed from the Arctic to temperate regions, in mountains; SIB: Irk (Makryi \& Lichtva 2005) and Bur (Urbanavichene \& Urbanavichus 1998, Kharpukhaeva 2010). It is reported for the first time for the Russian Far East.

Taxonomical notes. The species belongs to genus Placynthiella Elenkin that included only 5 species in Holarctic. Placynthiella differs from the closely related genera Trapelia M. Choisy and Trapeliopsis Hertel \& Gotth., which have the same type of ascus apices structure (Trapelia-type), by having a true exciple of brown-walled pseudoparenchymatous cells and paraphyses crowned with a dark brown apical cap (Smith et al. 2009). It differs from other species of genus Placynthiella by larger goniocysts (up to $100-300 \mu \mathrm{m}$ in diam.) which become yellowish when wet (Makarova 2003).

Examined specimens (new records). Sakhalin Island, vicinity of Yuzhno-Sakhalinsk, Susunaysky Range, Chekhov Peak, 4700'18.8"N 14250'29.1"E, alt. 1030 $\mathrm{m}$, boulders in the overgrowth of Pinus pumila, on soil, 28.06.2017, leg. S.V. Chesnokov (240).

\section{Sarea difformis (Fr.) Fr.}

Contributor: Sergey Chesnokov

Distribution and habitat. Inhabits resin on bark of Abies sachalinensis. In other regions it occurs on resin of 
coniferous trees. It is scattered distributed from the Subarctic to temperate regions; RFE: Pri (Chabanenko 2002, Skirina 2015b), Jew (Skirina 2015a), Kam (Himelbrant et al. 2019). It is reported for the first time for Sakhalin.

Taxonomical notes. It is a saprotropic fungus with a thallus lacking photobiont. It is characterized by the black plane apothecia with excipulum and multispored asci with small rounded spores (up to 100-200 per ascus).

Examined specimens (new records). Sakhalin Island, Korsakovsky District, "Laguna Busse" Nature Monument, vicinity of Vyselkovoe Lake, 46³3'57.1"N 143¹6'54,7"E, alt. $26 \mathrm{~m}$, Abies-Picea forest, on resin on bark of Abies sachalinensis, 24.05.2017, leg. S.V. Chesnokov (91).

\section{UMBILICARIACEAE Chevall.}

\section{Umbilicaria rossica (Dombr.) N.S. Golubk.}

Contributors: Svetlana I. Tchabanenko, Sergey

Chesnokov \& Evgeny A. Davydov

Distribution and habitat. Inhabits siliceous rocks. It is widely distributed in alpine belts of mountains; RFE: Kha (Tchabanenko 2002), Jew (Skirina 2015a), and Amu (Davydov 2017). It is reported for the first time for Sakhalin.

Taxonomical notes. The species belongs to the subgenus Lasallia (Davydov et al. 2017). It is often confused with Umbilicaria pensylvanica Hoffm., although these species only distantly related. Umbilicaria rossica is distingushed by its blackish erect lobulae, wrinkled and pruinose upper surface, subimmersed black pycnidae, finely papillose lower surface, and violet to reddish hymenium.

Examined specimens (new records). Sakhalin Island, Schmidt Peninsula, Elizabeth Cape, 54 $25^{\prime} 14.78^{\prime \prime} \mathrm{N}$ $142^{\circ} 42^{\prime} 12,0^{\prime \prime} \mathrm{E} 222 \mathrm{~m}$, stones and boulder outcrops in the NW range, on rock, 15.08.2005, S.I. Tchabanenko (s.n.); Nogliki District, headwaters of Chamgu River, on rock, 17.08.2006, leg. S.I. Tchabanenko (s.n.); vicinity of YuzhnoSakhalinsk, Susunaysky Range, Chekhov Peak, 4700'18.8"N $142^{\circ} 50^{\prime} 29.1$ "E, alt. $1030 \mathrm{~m}$, boulders in Pinus pumila thickets, on stone, 28.06.2017, leg. S.V. Chesnokov (238).

\section{Excluded taxa:}

\section{Caloplaca aurantiaca (Lightf.) Th. Fr.}

The specimen mentioned for Kunashir Island by Bredkina and al. (1992) was reidentified as Caloplaca gordejevii (Tomin) Oxner. Specimens examined: Kunashir Island. Kuril'sky State Nature Reserve, $35 \mathrm{~km}$ to S from YuzhnoKurilsk Sity, Saratovka cordon, on bark of Sambucus racemosa, 14.09.1989, L.I. Bredkina (LE).

\section{Collema subfurvum (Müll. Arg.) Degel}

The specimen mentioned for Kunashir Island by Bredkina and al. (1992) was reidentified as Leptogium saturninum (Dicks.) Nyl. Specimens examined: Kunashir Island. 35 km to $\mathrm{N}$ from of Yuzhno-Kurilsk Sity, Saratovka cordon, on the bark of deciduous tree, 14.09.1989, leg. L.I. Bredkina (LE).

\section{Lecidea sphaerella Hedl. (三 Biatora sylvana Körb)}

The specimen was reidentified as Biatora vernalis (L.) Fr. Specimens examined: Kunashir Island. Tret'yakovo, to S of Yuzhno-Kurilsk Sity, bark of Quercus sp. 20.09.1989, leg. L.I. Bredkina (LE).

\section{Lopadium pezizoideum (Ach.) Körb.}

The specimen mentioned for Kunashir Island by Bredkina and al. (1992) was reidentified as Lopadium disciforme (Flot.) Kullh. In the monograph by Tchabanenko (2002), the species is synonymized incorrectly with Lopadium disciforme (Flot.) Kullh. Both of these species are given in modern literature (Smith et al. 2009). Specimens examined: Kunashir Island. Tret'yakovo, in the South part of Island, on bark of coniferous tree, 20.09.1989, leg. L.I. Bredkina (LE).

\section{Megalospora atrorubricans subsp. sendaiensis (Räsänen) Sipman}

We studied specimen from Kunashir and Shikotan Islands (Insarov \& Pchelkin 1988). It is badly damaged by fungi, and hymenium completely destroyed and there are no spores. Therefore, it is impossible to determine it reliably. However, the studied specimens lacks soredia, which is distinguishing characteristic of Megalospora atrorubricans subsp. sendaiensis. Externally, the specimen looks like a widespread species Megalospora tuberculosa (Fée) Sipman. Specimens examined: Kunashir Island. Kuril'sky State Nature Reserve, on bark of Abies sachalinensis, 1985, leg. A.V. Pchelkin (herbarium of Kuril'sky State Nature Reserve).

\section{Ochrolechia turneri (Sm.) Hasselrot}

The specimen was reidentified as Ocbrolechia yasudae Vain. It is characterized by the presence of isidia and $\mathrm{C}+$ red reaction of thallus, instead $O$. turneri forming granular soredia and thallus C-. Specimens examined: Kunashir Island. Kuril'sky State Nature Reserve, to S from Yuzhno-Kurilsk Sity, Tret'yakovo, on bark of Quercus sp., 21.09.1989, leg. A.P. Ravinskaya (LE).

\section{Parmelina quercina (Willd.) Hale}

Nelson et al. (2012) mentioned, that reports of the distribution of P. quercina in the south of the Far East most likely relate to Parmelina yalungana (Zahlbr.) P.R. Nelson et Kepler.

\section{Phaeophyscia orbicularis (Neck.) Moberg}

The specimen mentioned for Kunashir Island by Bredkina and al. (1992) was reidentified as Physciella melanchra (Hue) Essl. due to the presence of a pale lower surface, while Phaeophyscia orbicularis characterized by black lower surface. Specimens examined: Kunashir Island. Tret'yakovo, to S from Yuzhno-Kurilsk Sity, on bark of Quercus sp., 20.09.1989, leg. L.I. Bredkina (LE).

\section{Pseudocyphellaria crocata (L.) Vain.}

In the herbarium LE, all specimens from the Far East were reidentified as P. perpetua McCune \& Miadlikowska. According to S.I. Tchabanenko (personal comment), all specimens published by her as $P$. crocata, also apply to $P$. perpetua.

\section{Schismatomma pericleum (Ach.) Branth \& Rostr.}

The specimens, published by Ezhkin \& Galanina (2014), were reidentified as Lecanographa amylacea (Ehrh. ex Pers.) Egea \& Torrente. Specimens examined: Sakhalin Island, Susunaysky Range, vicinity of Yuzhno-Sakhalinsk Sity, Bol'shevik Mt., foot of the mountain, northwest slope, $46^{\circ} 57.689^{\prime} \mathrm{N} 142^{\circ} 45.786^{\prime} \mathrm{E}$, alt. $160 \mathrm{~m}$, mixed forest, on bark of Alnus glutinosa, 10.06.2011, leg. A.K. Ezhkin (SAK); ibid, Rogatka River, 4658.010'N $142^{\circ} 46.455^{\prime} \mathrm{E}$, alt. $176 \mathrm{~m}$, floodplain forest, on bark of Alnus glutinosa, 10.10.2011, leg. A.K. Ezhkin (SAK).

\section{? Thelotrema foveolare Müll. Arg.}

The speices was published from Kunashir Island (Insarov \& Pchelkin 1988). It is badly damaged by fungi, and hymenium completely destroyed and there are no spores. Therefore, it is impossible to determine it reliably. Specimens examined: Kunashir Island. Kuril'sky State Nature Reserve, on bark of Abies sachalinensis, 1985, leg. A.V. Pchelkin

\section{Nephromopsis pseudocomplicata (Asahina) M.J. Lai (三Tuckneraria pseudocomplicata (Asahina) Randlane \& Saag, 三 Cetraria psendocomplicata Asahina)}

The specimen published by Bredkina et al. (1992) was reidentified as Nephromopsis nephromoides. Specimens examined: see Nephromopsis nephromoides. 
Umbilicaria pensylvanica Hoffm. (三 Lasallia pensylvanica (Hoffm.) Llano)

The specimen was reidentified as Umbilicaria rossica (Dombr.) N.S. Golubk. Specimens examined: see U. rossica.

Vulpicida tubulosus (Schaer.) J.-E. Mattsson \& M.J. Lai We studied specimen Vulpicida tubulosus in LE identified by J.-E. Mattsson, but morphology it's more suitable for Vulpicida juniperinus (L.) J.-E. Mattsson \& M.J. Lai. Specimens examined: Sakhalin Island, by the sea coast near Pil'vo village, 07.1894, leg. L.Ya. Shtenberg (LE).

\section{ACKNOWLEDGEMENTS}

The work was carried out in the frame of the institutional research project "Cryptogamic biota of Pacific Asia: taxonomy, biodiversity, species distribution" of the Botanical Garden-Institute of Far Eastern Branch of the Russian Academy of Sciences (work of S.V. Chesnokov, L.A. Konoreva). The study was partly financially supported by the Russian Foundation for Basic Research (grant no. 19-04-00074, work by L.A. Konoreva and S.V. Chesnokov) and grant of the Russian Foundation for Basic Research and the Japan Society for the Promotion of Science (no. 19-54-50010, work by S.V. Chesnokov, E.A. Davydov, L.S. Yakovchenko and Y. Ohmura).

\section{LITERATURE CITED}

Ahti, T. \& S. Stenroos 2013. Cladonia P. Browne. In: Nordic Lichen Flora, vol. 5, Cladoniaceae, (T. Ahti, S. Stenroos \& R. Moberg, eds), pp. 8-87, Museum of Evolution, Uppsala.

Ahti, T. 1980. Taxonomic revision of Cladonia gracilis and its allies. Annales botanici Fennici 17:195-243.

Andreev, M., Yu. Kotlov \& I. Makarova 1996. Checklist of lichens and lichenicolous fungi of the Russian Arctic. The Bryologist 99(2):137-169.

Arup, U. 2006. A new taxonomy of the Caloplaca citrina group in the Nordic countries, except Iceland. The Lichenologist 38(1):1-20.

Arup, U. \& E.S. Berlin 2011. A taxonomic study of Melanelixia fuliginosa in Europe. The Lichenologist 43(2):89-97.

Bendiksby, M. \& E. Timdal 2013. Molecular phylogenetics and taxonomy of Hypocenomyce sensu lato (Ascomycota: Lecanoromycetes): Extreme polyphyly and morphological/ ecological convergence. Taxon 62:940-956.

Blanco, O., A. Crespo, P.K. Divakar, T.L. Esslinger, D.L. Hawksworth \& H.T. Lumbsch 2004. Melanelixia and $M e$ lanohalea, two new genera segregated from Melanelia (Parmeliaceae) based on molecular and morphological data. Mycological Research 108(8):873-884.

Bredkina, L.I., A.N. Dobrysch, I.I. Makarova \& A.N. Titov 1992. To the lichen flora of Kunashir Island (Kuril Islands). Novosti sistematiki niashikh rastenii 28:90-94 (in Russian). ББредкина А.И., Аобрыш А.Н., Макарова И.И., Титов А.Н. 1992. К флоре Аишайников о-ва Кунашир (Курильские острова) / / Новости систематики низших растений. Т. 28. С. 90-94].

Cherdantseva, V.Ya., V.A. Bakalin, L.S. Yakovchenko \& S.S. Choi 2013. Bryophyte flora and lichen biota of Litovka Mt. (Livadiysky Range, Russian Manchuria). Komarovskie chteniya 61:9-49 (in Russian with English abstract). [ЧepАанцева В.Я., Бакалин В.А., Яковченко А.С., Чой С.С. 2013. Бриофлора и михенобиота горы Аитовка (Аи- вадийский хребет, Российская Маньчжурия) / / Комаровские чтения. Вып. 61. С. 9-49].

Chesnokov, S., L. Konoreva \& A. Paukov 2018. New species and records of saxicolous lichens from the Kodar Range (Trans-Baikal Territory, Russia). Plant and Fungal Systematics 63(1):11-21.

Coppins, B.J. 1983. A taxonomic study of the lichen genus Micarea in Europe. Bulletin of the British Museum (Natural History), Botany 11(2):17-214.

Czarnota, P. 2007. The lichen genus Micarea (Lecanorales, Ascomycota) in Poland. Polish Botanical Studies 23:1-199.

Czarnota, P. 2011. Micarea contexta and M. lynceola (Lichenized Ascomycota), new for Poland. Polish Botanical Journal 56(2):307-313.

Davydov, E.A. 2017. Family Umbilicariaceae. In: The Lichen Flora of Russia. Genus Protoparmelia, families Coenogoniaceae, Gyalectaceae and Umbilicariaceae, (M.P. Andreev, D.E. Himelbrant, eds), pp. 66-127, KMK Scientific Partnership, Moscow, Saint Petersburg (in Russian). [Аавылов E.A. 2017. Семейство Umbilicariaceae // ФАора Аишайников России: род Protoparmelia, семейства Coenogoniaceae, Gyalectaceae и Umbilicariaceae / отв. ред. М.П. Андреев, А.Е. Гимельбрант. М., СПб.: Товарищество научных изАаний КМК. С. 66-127].

Davydov, E.A., D. Peršoh \& G. Rambold 2017. Umbilicariaceae (lichenized Ascomycota) - trait evolution and a new generic concept. Taxon 66(6):1282-1303.

Dobrysch, A.A. \& I.I. Makarova 1998. Lichens of the genus Rhizocarpon Ramond ex DC. in the flora of Chukotka and Wrangel Island (North-East of Russia). Novosti sistematiki nizshikh rastenii 32:23-27 (in Russian). [Аобрыш A.A., Макарова И. И. 1998. Аишайники рода Rhizocarpon Ramond ex DC. во флоре Чукотки и острова Врангеля (Северо-Восток России) // Новости систематики низших растений. Т. 32. С. 23-27].

Ertz, D. \& A. Tehler 2011. The phylogeny of Arthoniales (Pezizomycotina) inferred from nucLSU and RPB2 sequences. Fungal Diversity 49:47-71.

Ezhkin, A.K. \& I.A. Galanina 2014. Additions to the lichen biota of the Sakhalin Island. Novosti sistematiki nizshikh rastenii 48:233-248 (in Russian with English abstract). [Ёжкин А.К., Галанина И.А. 2014. Аополнения к Аихенобиоте острова Сахалин // Новости систематики низших растений. Т. 48. С. 233-248].

Fryday, A.M. 2002. A revision of the species of the Rhizocarpon hochstetteri group occurring in the British Isles. The Lichenologist 34(6):451-477.

Fryday, A.M. 2005. The genus Porpidia in northern and western Europe, with special emphasis on collections from the British Isles. The Lichenologist 37(1):1-35.

Galanina, I.A. 2013. Lichens of fir-spruce and larch forests with the kuril bamboo understory in the south of Sakhalin Island. Vestnik Severo-Vostochnogo Nauchnogo Tsentra DVO RAN 2:86-94 (in Russian with English abstract). Галанина И. А. 2013. Аишайники пихтово-елового и Аиственничного Аесов с подлеском из бамбука курильского на юге о. Сахалин // Вестник СВНЦ $\triangle \mathrm{BO}$ PAH № 2. C. 86-94].

Galanina, I.A. 2016. Addition to the lichen biota of dune complexes of Central Yakutia. Botanicheskii Zhurnal 101: 1486-1497 (in Russian with English abstract). [Галанина И.А. 2016. Аополнение к михенобиоте Аюнных компмексов (Тукуланов) Центральной Якутии // Ботанический журнал. Т. 101, № 12. С. 1486-1497]. 
Gowan, S.P. 1989. The lichen genus Porpidia (Porpidiaceae) in North America. The Bryologist 92(1):25-59.

Hafellner, J. 2002. Studien an lichenicolen Pilzen und Flechten XI. Scoliciosporum vouauxii, eine lichenicole Flechte auf Ramalina-Arten. Herzogia 15:13-18.

Hafellner, J. 2004. Notes on Scoliciosporum intrusum. Fritschiana 49:29-41.

Hertel, H. \& M.P. Andreev 2003. On some saxicolous lecideoid lichens of the Beringian Region and adjacent areas of Eastern Siberia and the Russian Far East. The Bryologist 106(4):539-551.

Himelbrant D.E., I.S. Stepanchikova \& E.S. Kuznetsova 2014. Lichens. In: Vegetation cover of volcanic plateaus of Central Kamchatka, (V.Yu. Neshataeva, ed.), pp. 121-164, KMK Scientific Partnership, Moscow (in Russian). ГИимельбрант А.Е., Степанчикова И.С., Кузнецова Е.С. 2014. Аишайники // Растительный покров вулканических плато Центральной Камчатки / поА. реА. В.Ю. Нешатаева. М.: Товарищество научных изданий КМК. C. 121-164].

Himelbrant, D.E., I.S. Stepanchikova, T. Ahti \& V.Yu. Neshataeva 2019. The first lichenological survey in Koryakia (Northern Kamchatka, Russia) - the last unexplored part of Beringia. Novosti sistematiki nizshikh rastenii 53(1):107-142.

Hinds, J.W., A.M. Fryday \& A.C. Dibble 2002. Three additions to the lichen flora of North America from Mt. Katahdin, Maine. Evansia 19:137-141.

Insarov, G.E. \& A.V. Pchelkin 1988. Quantitative characteristics of the status of epiphytic lichen flora of the Kuril reserve. Moscow. 175 pp. (in Russian). [Инсаров Г.Э., Пчелкин А.В. 1988. Количественные характеристики состояния эпифитной михенофморы Курильского заповедника. М. 175 с.].

Jørgensen, P.M. 2007. Collemataceae. In: Nordic Lichen Flora, vol. 3, Cyanolichens, (T. Ahti, P.M. Jørgensen, H. Kristinsson, R. Moberg, U. Søchting \& G. Thor, eds), pp. 14-42, Museum of Evolution, Uppsala.

Joshi, S., D.K. Upreti, S.-O. Oh, T.T. Nguyen, A.D. Nguyen \& J.-S. Hur 2015. New records of crustose lichens and a lichenicolous Arthonia from Vietnam. Mycotaxon 130(2): 329-336.

Kantvilas, G. 2009. The genus Mycoblastus in the cool temperate Southern Hemisphere, with special reference to Tasmania. The Lichenologist 41(2):151-178.

Kharpukhaeva, T.M. 2010. Lichens of Drherginskii State Nature Reserve. BSC SB RAS Publishers, Ulan-Ude, 156 pp. (in Russian with English abstract). ХХарпухаева T.M. 2010. Аишайники Ажергинского государственного природного заповедника. УАан-УАэ: ИзА-во БНЦ СО PAH. 156 c.].

Kharpukhaeva, T.M. 2013. Findings of new and rare lichens in Republic of Buryatia. Botanicheskii zhurnal 98(3):364 371 (in Russian with English abstract). ХХарпухаева T.M. 2013. Находки новых и редких видов Аишайников Аля Республики Бурятия // Ботанический журнац. Т. 98, № 3. C. 364-371].

Kharpukhaeva, T.M. 2015. Lichens of nature park "Shumak" (East Sayan Mts, Buryatia Republic). Rastitelnyi Mir Aqiatskoy Rossii 1(17):11-19 (in Russian with English abstract). ХХарпухаева T.M. 2015. Аишайники природного парка "Шумак" (Восточный Саян, Республика Бурятия) / / Растительный мир Азиатской России. № 1(17). C. 11-19].

Kharpukhaeva, T.M. 2017. Epiphytic lichens inhabiting Chosenia arbutifolia in the Republic of Buryatia. Priroda
Vnutrennei Azii 1(2):37-42 (in Russian with English abstract). [Харпухаева Т.M. 2017. Эпифитные мишайники, обитающие на Chosenia arbutifolia в Республике Бурятия // Природа внутренней Азии № 1(2). С. 37-42].

Khodosovtsev, A., E. Kuznetzova \& D. Himelbrant 2004. Lichen genus Caloplaca on the Kamchatka Peninsula (Russian Far East). Botanica Lithuanica 10(3):195-208.

Korolev, Yu.B. \& T.Yu. Tolpysheva 1980. Essay on the lichen flora of station "Kontakt" (Verkhnekolymskoye highlands). Novosti sistematiki nizshikh rastenii 17:137-149 (in Russian). [Королев Ю.Б., Толпышева Т.Ю. 1980. Очерк флоры мишайников стационара «Контакт» (Верхнеколымское нагорье). Новости систематики низших растений. Т. 17. С. 137-149].

Kotlov, Yu.V. 1995. Materials for lichen flora of the Verkhnekolymskoe Highlands. Novosti sistematiki nizshikh rastenii 30:66-72 (in Russian). [Котлов Ю.В. 1995. Материалы к михенофлоре Верхнеколымского нагорья / / Новости систематики низших растений. Т. 30. С. 66-72].

Makarova, I.I. 2003. Family Trapeliaceae. In: Handbook of the lichens of Russia 8, (N.S. Golubkova, ed.), pp. 239-258, Nauka, Saint Petersburg (in Russian). [Макарова И.И. 2003. Сем. Trapeliaceae // Определитель мишайников России. Вып. 8. / отв. ред. Н.С. Голуббкова. Спб.: Наука. C. 239-258].

Makryi, T.V. \& A.V. Lishtva 2005. Lichens. In: Biota of the Vitim Reserve: flora (G.A. Peshkova, ed.), pp. 115-175, Geo, Novosibirsk (in Russian). [Макрый T.B., Аиштва A.B. 2005. Аишайники / / Биота Витимского заповедника: флора / отв. реА. Г.А. Пешкова. Новосибирск: «Гео», С. 115-175].

Malíček, J. 2014. A revision of the epiphytic species of the Lecanora subfusca group (Lecanoraceae, Ascomycota) in the Czech Republic. The Lichenologist 46(4):489-513.

Moberg, R. 2002. Physcia. In: Nordic Lichen Flora, vol. 2. Physciaceae, (T. Ahti, P.M. Jørgensen, H. Kristinsson, R. Moberg, U. Søchting \& G. Thor, eds), pp. 33-38, TH-tryck $\mathrm{AB}$, Uddevalla.

Nelson, P.R., R. Kepler, J. Walton, J. Fankhauser, L. Nelson \& W.L. Song 2012. Parmelina yalungana resurrected and reported from Alaska, China and Russia. The Bryologist 115(4):557-565.

Neshataeva, V.Yu., I.V. Chernyadjeva, D.E. Himelbrant, E.S. Kuznetsova, V.Yu. Neshatayev, O.A. Chernyagina \& M.V. Dulin 2005. Pristine flood-plain forests of southwest Kamchatka (species composition and the community characteristics). In: Conservation of biodiversity of Kamchatka and coastal waters: Materials of $V$ scientific conference, (R.S. Moiseev, A.M. Tokranov, O.A. Chernyagina, eds), pp. 70-102, Kamchatpress, Petropavlovsk-Kamchatsky (in Russian with English abstract). [Нешатаева В.Ю., Чернядьева И.В., Гимельбрант А.Е., Кузнецова Е.С., Нешатаев В.Ю., Чернягина О.А., Аулин М.В. 2005. Пойменные меса Юго-Западной Камчатки (фмористическая и ценотическая характеристика) // Аоклады V научной конференции «Сохранение биоразнообразия Кам-

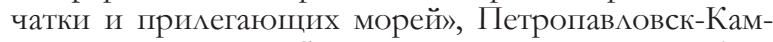

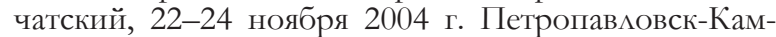
чатский: Камчатпресс. С. 70-102].

Otálora, M.A.G., P.M. Jørgensen \& M. Wedin 2014. A revised generic classification of the jelly lichens, Collemataceae. Fungal Diversity 64:275-293.

Øvstedal, D.O., T. Tønsberg \& A. Elvebakk 2009. The lichen flora of Svalbard. Sommerfeltia 33:1-393.

Pchelkin, A.V. 2008. The lichenoflora of Norsky Reserve. In: Collection of articles on the 10th anniversary of the Norsky 
reserve, (N.N. Kolobaev, ed.), pp. 69-88, Zeya, Blagoveshchensk, Fevralsk (in Russian). [Пчёлкин А.В. 2008. Аихенофцора Норского заповедника / / Сборник статей к 10-летию Норского заповедника / под ред. Н.Н. Колобаева. Благовещенск; Февральск: Зея. С. 69-88].

Poryadina, L.N. 2005. Lichens. In: The diversity of the plant world of Yakutia, (N.S. Danilov, ed.), pp. 126-149, Izdatel'stvo Sibirskogo Otdeleniya RAN, Novosibirsk (in Russian). [Порядина А.Н. 2005. Аишайники // Разнообразие растительного мира Якутии / отв. редактор Н.С. Аанилова. Новосибирск: ИзА-во СО РАН. С. 126-149].

Rambold, G. 1989. A monograph of the saxicolous lecideoid lichens of Australia (Excl. Tasmania) (Bibliotheca Lichenologica, 34). J. Cramer, Berlin-Stuttgart. 345 pp.

Randlane, T. \& A. Saag, 2001. Cetrarioid lichens containing usnic acid from the Tibetan area. Mycotaxon 80:389-425.

Ryan, B.D. 2002. Rhizoplaca. In: Lichen Flora of the Greater Sonoran Desert Region, vol. 1, (T.H. Nash III, B.D. Ryan, C. Gries, F. Bongartz, eds), pp. 442-448, Arizona State University, Tempe, Arizona.

Savicz, V.P. \& A.A. Elenkin 1950. Introduction to the lichen flora of the Asian part of the USSR. Trudy BIN AN SSSR. Seriya II. Sporovye rastenia 6:181-343 (in Russian). [Савич В.П., Еленкин А.А. 1950. Введение к флоре мишайников Азиатской части СССР / / Труды БИН АН СССР. Серия II. Споровые растения. Вып. 6. С. 181-343].

Skirin, F.V. \& I.F. Skirina 2012. The ecological-substrate distribution of epiphytic lichens in fir-spruce and pinebroadleaved forests of south Sikhote-Alin. Turczaninowia 15(1):70-79 (in Russian with English abstract). [Скирин Ф.В., Скирина И.Ф. 2012. Эколого-субстратная приуроченность эпифитных мишайников пихтово-еловых и кеАрово-широколиственных $е$ есов южного Сихотэ-Алиня // Turczaninowia. Вып. 15, № 1. С. 70-79].

Skirina, I.F. 2010. Addition to lichen flora of islands and coast of Peter the Great Bay (the sea of Japan, Primori Territory). Novosti sistematiki nisshikh rastenii 44:221-236 (in Russian with English abstract). [Скирина И.Ф. 2010. Аополнение к михенофлоре островов и побережья залива Петра Великого (Японское море, Приморский край) // Новости систематики низших растений. T. 44. C. 221-236].

Skirina, I.F. 2012. An annotated list of lichens of Bolshekhekhtsirsky Nature Reserve (Khabarovsk Territory). Novosti sistematiki nirshikh rastenii 46:202-216 (in Russian with English abstract). [Скирина И.Ф. 2012. Список мишайников Большехехцирского заповедника (Хабаровский Край) // Новости систематики низших растений. Т. 46. С. 202-216].

Skirina, I.F. 2015a. Lichen list of "Bastak" natural reserve (Russia). Biodiversity and Environment of Far East Reserves 4: 28-87 (in Russian with English abstract). [Скирина И.Ф 2015а. Список Аишайников заповедника «Бастак» // Биота и среда заповедников Аальнего Востока. № 4. C. 28-87].

Skirina, I.F. 2015b. List of lichens of Sikhote-Alin Reserve (Russia). Biodiversity and Environment of Far East Reserves 3:10-102 (in Russian with English abstract). [Скирина И.Ф. 2015b. Список мишайников Сихотэ-Алинского заповедника / / Биота и среда заповедников Аальнего Востока. № 3. С. 10-102].

Skirina, I.F. 2017. List of lichens of "Kedrovaya Pad" State Nature Reserve. Biodiversity and Environment of Far East Reserves 1(10):75-122 (in Russian with English abstract).
[Скирина И.Ф. 2017. Список мишайников заповедника «КеАровая Падь» // Биота и среда заповедников Аальнего Востока. № 1(10). С. 75-122].

Smith, C.W., A. Aptroot, B.J. Coppins, A. Fletcher, O.L. Gilbert, P.W. James \& P.A. Wolseley 2009. The lichen flora of Great Britain and Ireland. British Lichen Society, London. 1046 p.

Šoun, J., J. Vondrák, U. Søchting, P. Hrouzek, A. Khodosovtsev \& U. Arup 2011. Taxonomy and phylogeny of the Caloplaca cerina group in Europe. The Lichenologist 43(2): 113-135.

Stenroos, S. 1989. Taxonomy of the Cladonia coccifera group. 1. Annales botanici Fennici 26:157-168.

Stenroos, S., J. Hyvönen, Myllys L., A. Thell \& T. Ahti 2002. Phylogeny of the genus Cladonia s.lat. (Cladoniaceae, Ascomycetes) inferred from molecular, morphological, and chemical data. Cladistics 18:237-278.

Stepanchikova, I.S., D.E. Himelbrant, A.V. Dyomina \& G.M. Tagirdzhanova 2015. The lichens and allied fungi of the Zapadny Kotlin Protected Area and its vicinities (Saint Petersburg). Novosti sistematiki nizshikh rastenii 49:265-281.

Stepanchikova, I.S., D.E. Himelbrant, U. Schiefelbein, J. Motiejūnaite, T. Ahti \& M.P. Andreev 2019. The lichens of Moshchny Island (Lavansaari) - one of the remote islands in the Gulf of Finland. Folia Cryptogamica Estonica 56:31-52.

Tchabanenko, S.I. 2002. Checklist of the flora of lichens in the south of the Russian Far East. Dalnauka, Vladivostok, 232 pp. (in Russian). [Чабаненко С.И. 2002. Конспект флоры Аишайников юга Российского Аальнего Востока. ВАадивосток: Аальнаука. 232 с.].

Tibell, L. 1999. Calicioid lichens and fungi. In: Nordic Lichen Flora, vol. 1, Introductory parts, Calicioid lichens and fungi, (T. Ahti, P.M. Jørgensen, H. Kristinsson, R. Moberg, U. Søchting \& G. Thor, eds), pp. 20-71, The Nordic Lichen Society, Uddevalla.

Timdal, E. 1984. The delimitation of Psora (Lecideaceae) and related genera, with notes on some species. Nordic journal of botany 4:525-540.

Timdal, E. 1991. Anamylopsora, a new genus in the Lecideaceae. Mycotaxon 42:249-254.

Titov, A.N. 2006. Mycocalicioid fungi (order Mycocaliciales) of Holarctic. KMK Scientific Partnership, Moscow, 296 pp. (in Russian). [Титов А.Н. 2006. Микокалициевые грибы (порядок Mycocaliciales) Голарктики. М.: Товарищество научных изданий КМК. 296 с.].

Tolpysheva, T.Yu. \& E.D. Zhiryakova 1988. The lichens of Picea ajanensis (Lindl. Eт Gord.) Fisch. Ex Carr. and P. koraiensis Nakai. Novosti sistematiki nizshikh rastenii 25:137147 (in Russian). [Толпышева Т.Ю., Жирякова Е.А. 1988. Аишайники Picea ajanensis (Lindl. Eт Gord.) Fisch. Ex Carr. и P. koraiensis Nakai // Новости систематики низших растений. Т. 25. С. 137-147].

Urbanavichene, I.N. \& G.P. Urbanavichus 1998. Lichens of the Baikal Reserve (annotated species list). Flora and fauna of Reserves 68:1-55 (in Russian). ГУрбанавичене И.Н., Урбанавичюс Г.П. 1998. Аишайники Байкальского заповедника (аннотированный список видов) // ФАора и фауна заповедников. Вып. 68. С. 1-55].

Urbanavichene, I.N. 2008. The genus Physcia (Schreb.) Michx. In: Handbook of the lichens of Russia 10, (N.S. Golubkova, ed.), pp. 258-276, Nauka, Saint Petersburg (in Russian). [Урбанавичене И.Н. 2008. Род Physcia (Schreb.) Michx. // Определитель мишайников России / отв. реА. Н.С. Голубкова. Спб.: Наука. Вып. 10. С. 258-276]. 
Urbanavichus, G. \& I. Urbanavichene 2017. New and noteworthy records of lichen-forming and lichenicolous fungi from Abrau Peninsula (NW Caucasus, Russia). Flora Mediterranea 27:175-184.

Urbanavichus, G.P. \& I.N. Urbanavichene 2017a. Contribution to the lichen flora of Erzi Nature Reserve, Republic of Ingushetia, North Caucasus, Russia. Willdenowia 47(3): 227-236

Velikanov, A.V. \& I.F. Skirina 2012. Lichens of Lanzhinskiye Mountains (Okhotia). Vestnik Severo-Vostochnogo Nauchnogo Tsentra DVO RAN 2:69-77 (in Russian with English abstract). [Великанов А.В., Скирина И.Ф. 2012. Аишайники Аанжинских гор (Охотия) // Вестник СВНЦ $\triangle \mathrm{BO}$ РАН. № 2. С. 69-77].

Vondrák, J., P. Ríha, U. Arup \& U. Søchting 2009. The taxonomy of the Caloplaca citrina group (Teloschistaceae) in the Black Sea region; with contributions to the cryptic species concept in lichenology. The Lichenologist 41(6):571-604.

Vondrák, J., O. Redchenko, D. Himelbrant, I. Stepanchikova \& E. Kuznetsova 2010a. Some sterile Caloplaca crusts identified by molecular data from the Leningrad region (Russia). Folia Cryptogamica Estonica 47:97-99.

Vondrák, J., J. Šoun, M.Z. Søgaard, U. Søchting, U. Arup 2010b. Caloplaca phlogina, a lichen with two facies; an example of infraspecific variability resulting in the description of a redundant species. The Lichenologist 42(6):685-692.

Vondrák, J., A. Ismailov \& G. Urbanavichus 2017. Lichens of the family Teloschistaceae in Dagestan, an eastern part of the Caucasian biodiversity hot-spot. Nova Hedwigia 104(4):483-498.

Westberg, M. \& A. Thell 2011a. Melanelixia. In: Nordic Lichen Flora, vol. 4, Parmeliaceae, (A. Thell \& R. Moberg, eds), pp. 72-76, Museum of Evolution, Uppsala.

Westberg, M. \& A. Thell 2011b. Melanohalea. In: Nordic Lichen Flora, vol. 4, Parmeliaceae, (A. Thell \& R. Moberg, eds), pp. 76-81, Museum of Evolution, Uppsala.

Westberg, M. \& A. Thell 2011c. Menegazzia. In: Nordic Lichen Flora, vol. 4, Parmeliaceae, (A. Thell \& R. Moberg, eds), pp. 81-83, Museum of Evolution, Uppsala.

Westberg, M., T. Ahti \& A. Thell 2011. Hypogymnia. In: Nordic Lichen Flora, vol. 4, Parmeliaceae, (A. Thell \& R. Moberg, eds), pp. 56-62, Museum of Evolution, Uppsala.

Yakovchenko, L.S. 2009. Lichens of the Sokhondinskiy Biosphere Reserve. Komarovskie chteniya 56:120-151 (in
Russian). [Яковченко А.С. 2009. Аишайники СохонАинского биосферного заповедника // Комаровские чтения. Вып. 56. С. 120-151].

Yakovchenko, L.S., E.A. Davydov, A.G. Paukov \& Y. Ohmura 2019. New records of lichens from the Russian Far East. I. Fuscidea submollis and other arctic-alpine species. Turczaninowia 22(3):91-96.

Yakovchenko, L.S., I.A. Galanina, E.V. Malashkina \& V.A. Bakalin 2013. Mosses and lichens in the minimally disturbed forest communities of the Lower Amur River area (Russian Far East). Komarovskie cbteniya 60:9-68 (in Russian with English abstract). [Яковченко А.С., Галанина И.А., Малашкина Е.В., Бакалин В.А. 2013. Мохообразные и мишайники малонарушенных месных сообществ в нижнем Приамурье (российский Аальний Восток) // Комаровские чтения. Т. 60. С. 9-68].

Yakovchenko, L.S., E.A. Davydov, Y. Ohmura \& C. Printzen 2019. The phylogenetic position of species of Lecanora s. lat. containing calycin and usnic acid, with the description of Lecanora solaris Yakovchenko \& Davydov sp. nov. The Lichenologist 51(2):147-156.

Zhdanov, I .S. 2014a. Additions to the lichen flora of Central Siberian Biosphere Reserve (Krasnoyarsk Territory). Novosti sistematiki niashikh rastenii 47:200-214 (in Russian with English abstract). [ЖАанов И.С. 2014а. Аополнения к михенофлоре Центральносибирского Биосферного заповедника (Красноярский край) // Новости систематики низших растений. Т. 47. С. 200-214].

Zhdanov, I.S. 2014b. Rare and interesting lichen records from the Primorye Territory (Russia). Novosti sistematiki nizshikh rastenii 48:249-255 (in Russian with English abstract). [ЖАанов И.С. 2014b. Редкие и интересные михенологические находки в Приморском крае // Новости систематики низших растений. Т. 48. С. 249-255].

Zheludeva, E.V. 2015. Lichen species from North-Eastern Priokhotye (Okhotsk Sea region) new for Magadan region. Turczaninowia 18(4):5-15 (in Russian with English abstract). [Желудева Е.В. 2015. Новые Аля Магаданской области виды Аишайников из северо-восточного Приохотья // Turczaninowia. T.18, № 4. C. 5-15].

Zheludeva, E.V. 2017. New records of lichen species from Magadan region. Turczaninowia 20(2):64-74 [Желудева Е.В. 2017. Новинки михенофморы Магаданской области // Turczaninowia. T. 20, № 2. C. 64-74]. 